\title{
How do structural and agent-based factors influence the effectiveness of incentive policies? A spatially explicit agent-based model to optimize woodland-for-water PES policy design at the local level
}

\author{
Eulàlia Baulenas $^{1}, \underline{\text { Teresa Baiges }}^{2}, \underline{\text { Teresa Cervera }}^{2}$ and $^{\text {Claudia Pahl-Wostl }}{ }^{3}$
}

\begin{abstract}
A key factor in the resilience of water and forest ecosystems in the face of climate variability is the management decisions taken by the individuals responsible for them, from public officials to private owners. The presence of economic and other non-material incentives can modify the decision-making processes of these individuals and thereby avoid current socioeconomic trends in Mediterranean forested areas such as land abandonment and its detrimental consequences for both social and ecological systems. In this article, we created a spatially explicit agent-based model to observe the effects of the implementation of a woodland-for-water payment for ecosystem services scheme in a local area in Catalonia (NE Spain). The results of the model show that the policy design that supports recurrent management practices obtains the same results at the 25 -year mark that other policy designs at the end of the modeled period in number of managed hectares. This design entails the presence of a local intermediary, financial coverage of the management changes to improve water conditions, and the targeting of only one environmental goal, thereby avoiding the ecosystem trade-offs that can arise when two or more goals are targeted. In this design, the first generation of forest owners engaging in behavior change would benefit from their actions, which is also key for maintaining their engagement with the payments for ecosystem services scheme.
\end{abstract}

Key Words: agent-based model simulation; forest; payment for ecosystem services; policy integration; water

\section{INTRODUCTION}

Forest cover in Spain has increased from a $12.5 \%$ in the 19 th century to a current $30 \%$ of total land area. Although this increase was partially due to administration-led reforestation and afforestation programs (Vadell et al. 2016), land abandonment has also been a major contributor since the 1960s (Cervera et al. 2019). This land use change is said to be due to low profitability of forests and the abandonment of management practices, as well as interrelated rural-urban migration dynamics (Górriz-Mifsud et al. 2016). This situation is not idiosyncratic of Spain but rather common across Mediterranean countries (Feranec et al. 2010), Eastern Europe (Kuemmerle et al. 2011), and it is an increasingly foreseeable scenario in continental Europe (MacDonald et al. 2000). Although forest cover increase could be a mitigation measure against climate change (Fox 2019), in arid and semi-arid climates the advance of untargeted revegetation can have negative impacts at ecological, landscape, and socioeconomic levels (Lasanta et al. 2017). Among such, forest abandonment implies forest densification with higher impact on drought stress (De Cáceres et al. 2015), land degradation (Symeonakis et al. 2007), and it can lead to a decrease of water availability (García-Ruiz and Lana-Renault 2011) in an already general context of water scarcity (Mekonnen and Hoekstra 2016). Under these scenarios, abandoned land area is easily converted into shrubland, which increases the risk and intensity of wildfire events (Moreira and Russo 2007, Badia et al. 2019) and limits the resilience of the ecosystems because of the slowness of passive regeneration processes (Navarro and Pereira 2015).

There are several policy responses available to counteract the consequences of land abandonment, among which is the potential loss of ecosystem services (Mansourian et al. 2005). One of these, promoted by international (OECD 2010) and European (EC
2012) institutions alike, is the use of payments for ecosystem services $^{[1]}$ (PES) to alter natural resource management decisions to include environmental objectives. Despite attracting some criticism (Fletcher and Büscher 2017), this instrument has been implemented around the globe with enough mixed results to enable an array of possible policy designs (Sattler and Matzdorf 2013, Engel 2016). These recommendations have greatly advanced our understanding of PES schemes, but they rely heavily on examples from developed countries (see, e.g., Wunder 2005, Engel et al. 2008, Muradian et al. 2010). Because the context in which PES are embedded is seen as key for their performance (Lundberg et al. 2018, Wunder et al. 2018), in the current article we distil the lessons obtained from EU studies with special focus on the Mediterranean area ${ }^{[2]}$, which is the location of our case study. Our main aim is to analyze the interlinkage between PES policy design, provision of ecosystem services, and forest abandonment/ management dynamics adopted by landowners, whose long-term behavior modification is key to reaching the ecological objectives of the policy in place (Arriagada and Perrings 2013).

Studies from industrialized countries show the influence from micro-level socio-demographic factors on landholder PES participation. Studies point out age, training, farm size, and strength of the tenure as having an effect on the adoption of environmental practices at least in agriculture and with discrepancies on the magnitude and direction of effects (Cranford 2014). There is a similar lack of consensus with respect to exogenous factors such as the effect of economic coverage. Studies on woodland-for-water PES schemes and nature conservation suggest that financial incentives need to surpass the actual costs of the management change for landowners to participate (Kline et al. 2000, Pujol et al. 2006, Ferranti et al. 2017). Other studies claim that financial incentives are not sufficient (Kilgore et al. 
2007) and that all alternatives were rejected by landowners if they required a change in their practices (Serbruyns and Luyssaert 2006). Apparently, the reason behind these differences is the presence of owner typologies among the forest owner community of a given country, with some owners always willing to change their behavior, while others would not change it under any condition (Boon et al. 2004, Hogl et al. 2005, Hujala et al. 2007, Ní Dhubháin et al. 2007, Makkonen et al. 2015).

However, even when a high percentage of landowners adhere to a PES policy, it is uncertain what the long-term effects of the policy will be on the ecological system (Pahl-Wostl 2007). The main reason is the effects of climate change at local, regional, and global scales make likely that future conditions of the managed ecosystem will be different from those under which the policy was designed (Millar et al. 2007). In coupled social-ecological systems (SES), uncertainties regarding outputs are accepted as the norm and they should be incorporated in the design of policy and management practices (Folke 2006). Disregarding this could lead to policy failure independent of wide stakeholder participation (Medema et al. 2008). In summary, PES effectiveness is not only based on human actions, but also on the capacity of the program design to accommodate two additional aspects: the ecological variability of the targeted geographical area (Chen et al. 2014), and the uncertainty around how the ecosystem will respond to changes in management practices (Jack et al. 2008). Some PES scholars frame it as the interplay between context, design, and implementation (Wunder et al. 2018).

Because the study of PES cannot be decoupled from either social or ecological systems, nor from its context, with this study we aim to contribute to the debate through the design of a spatially explicit agent-based model (ABM). ABM has been found useful to study the adequacy of different policy instruments in the case of farmers (Janssen et al. 2000), on the management of lake eutrophication (Janssen 2001), and also for non-spatially targeted PES schemes (Lundberg et al. 2018) and spatially targeted schemes in China (An et al. 2005). ABM has a growing presence in the literature on coupled social-ecological systems because it allows simplified representation of complex real-world issues while at the same time introducing a variety of intervening elements (An et al. 2005). One such element is agent heterogeneity, by which there are groups with different characteristics, interests, and behaviors (Pahl-Wostl 2002), but also the interaction of processes that happen at different scales (An 2012). Participatory ABM, specifically, includes the stakeholders at different stages of the modeling process (Guyot and Honiden 2006). In our case, stakeholders were included at the outset of the model design and the discussions addressed design options to increase the likelihood of PES acceptance (Horne 2006, Getzner et al. 2018).

With our model, we simulate the effects of different PES scheme designs on individual behavior (the social) and on water and forest conditions under variable climate conditions (the ecological). Our research question is, how do structural and agent-based factors influence the effectiveness of an incentive policy? To address it, we first conducted a literature review on EU-based PES schemes to extract best practice on PES policy design. Second, we organized a workshop on a river basin in NE Spain in which the design of a woodland-for-water PES scheme was discussed with regional authorities and local stakeholders, including forest owners. We used the information obtained from the workshop to contrast the results of the literature review. Third, we developed a spatially explicit $\mathrm{ABM}^{[3]}$ for this geographical area, to study how different design characteristics of PES schemes influence longterm effects on both social and ecological systems. The ABM is based on three sub-models. (1) The social, based on behavioral models of forest owners; (2) the ecological, based on climate models for the local area studied using the GOTILWA+ model (see Methods); and (3) the policy-structural, which contains different PES design characteristics obtained from the literature review on EU PES schemes and contrasted with the results of the workshop.

\section{METHODS}

\section{Study area}

We chose the geographic area of the Rialb River Basin in Catalonia (Fig. 1), NE Spain, to develop our ABM, because it allowed us to observe abandonment/management dynamics as part of our research aim, which includes the exploration of interlinkages among policy design, ES provision, and behavioral responses. This area, specifically, is exemplary of a case of land use abandonment (Consorci Segre Rialb 2018). Additionally, we had access to information required for our model development.

Fig. 1. Forest cover change on the Rialb River Basin (19932009). Grey maps obtained from http://www.segrerialb.cat/ show the location of the Rialb river basin within Europe and the region of Catalonia: names display sub-regional capitals. The forst cover change map was produced by the Centre of Forest Property of Catalonia from raster data (MCSC v1 \& v4), obtained from the Catalan Forest Reaserach Institution (CREAF).

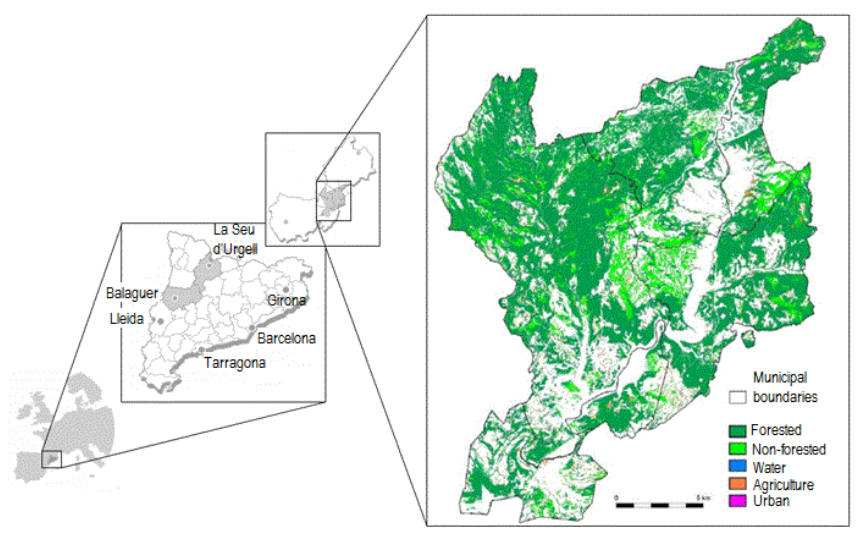

The basin has an arid continental Mediterranean climate characterized by two distinct seasons: a semi-arid season $\left(\sim 130 \mathrm{~mm} / \mathrm{av} 20^{\circ} \mathrm{C}\right)$ and a dry-cold season $\left(\sim 557 \mathrm{~mm} / \mathrm{av} 2.7^{\circ} \mathrm{C}\right.$ in the coldest months and north of the area because of the influence of the Pre-Pyrenees geology). At the socioeconomic level, the main city Baronia de Rialb has 231 inhabitants, a decline in inhabitant number since 2007 when 285 inhabitants were registered (Idescat 2018). This reflects the overall socioeconomic trends of depopulation and an aging population present in many rural areas of Spain (Serra et al. 2014). Land tenure is predominantly private and only $6.6 \%$ of the area is for public 
utility and selected to be managed to be "conserved and improved in relation to the influence of forest on hydrology" ( $\$ 11$, Catalan Forest Law 6). The number of landowners in the area is estimated at 1098 as of official records from the 2010 register $^{[4]}$. The area extends across $350.3 \mathrm{~km}^{2}$ and around $80 \%$ of it is covered by forest mass (FTiP 2003). The majority of the forested land continues to be private, with approximately $260 \mathrm{~km}^{2}$ of the area. The codes (colors) in Fig. 1 indicate the land cover changes that occurred between the years 1993 and 2009, with an increase of forested areas as well as the main illustration of the land abandonment processes experienced in the region.

\section{Model overview}

To describe our model we used the Overview, Design Concepts and Details (ODD) protoco ${ }^{[5]}$ by Grimm and colleagues in their 2010 updated version (Grimm et al. 2010). The protocol is increasingly used among the ABM community to improve communication as well as replication and extensions of the model.

The purpose of the proposed agent-based model is to contribute to the PES policy design, implementation, and context debate (Wunder et al. 2018). We used the case for a woodland-for-water payment for ecosystem services (PES) and modeled its implementation in a local area of Catalonia (NE Spain). Our research question was the following: how do structural and agentbased factors affect the effectiveness of an incentive policy to integrate the forest and water sector? By structural factors, we meant different designs of a PES policy. For agent-based factors, we used the literature on landowner behavioral studies about reception and reaction to incentive policies from Europeanfocused studies. By success, we understood that both the ecological but also social goals of the policy are reached effectively ${ }^{[6]}$. Our focus in Europe surges from the general context of land abandonment that many Mediterranean areas and Eastern countries are experiencing, and the growing interest from policy makers and practitioners on the implementation of PES schemes to ameliorate this situation. Specifically in woodland-for-water, the various services provided by forest and water are categorized in policy and the literature as provisioning, regulating, supporting, and cultural (Báliková et al. 2020). In this article, we focus on provisioning services (recharge of groundwater).

\section{Structural sub-model: PES policy design}

To select the literature for the review of EU-based best practices, we searched in Web of Science for the keywords "payment for ecosystem services" or "payment for environmental services" (Wunder 2015) and named each EU member state as well as "Europe" (including UK). From this search, we obtained 236 articles. We first examined the abstracts of the articles and discharged those deemed outside our scope following our definition of PES, e.g., Natura 2000 payments or forest subsidies. In a second step, which was performed by two of the authors in parallel, 59 studies were deemed relevant for the current study. We obtained the following information: country/ies, type of scheme (PES or Agri-environment schemes, see footnote 2), field (e.g., forest, agriculture), method, conclusion, summary, and if the PES was in place or it was a theoretical article. These criteria allowed us to select those articles that exclusively addressed PES from empirical cases only. Following the final selection, we summarized best practices based on 16 of the studies. The results were contrasted with those obtained during the workshop with stakeholders.
The half-day workshop was the second held in the Rialb river basin area in the context of an EU-funded project. The organizers were the Forest Ownership Centre of Catalonia (CPF) in coordination with the Catalan Forest Research and Technology Centre (CTFC). There were 25 participants from the local, subregional, and regional administrations, forest owners, and representatives of agricultural and tourism associations. The participant selection was based on a stakeholder analysis performed in the first stage of the EU project. The workshop started with a presentation of the goals - the pilot implementation of a PES scheme in the area-and presented different ways in which a PES can be designed. Following this, the discussions among participants were designed in two main lines of inquiry: who pays and who receives it, as well as how. Two workshop coordinators were present in each group, one for taking meeting minutes and a moderator. The discussion raised within each group was summarized in a final report ${ }^{[7]}$. In general, the participants were very supportive of an incentive mechanism to support forest management to improve water resources, but highlighted strongly the need to implement several communication campaigns to improve adherence. Table 1 shows the factors identified in the literature as best practice in PES design and the workshop conclusions in relation to each of the practice.

The design of the policy is expected to trigger different behavioral responses in forest owners. These responses are the types of forest management forest owners will choose. In this study, these decisions are based on the forest management guides called ORGEST (Sustainable Forest management Guides of Catalonia; Piqué et al. 2017). In these, there are two general management models per tree species considering improvement of water quantity. From the recommendations in these guides, we use the short- and long-term periods for selected thinning (15 and 35 years for conifers and broadleaf, respectively) and 50 and 100 years for end of rotation cutting with natural regeneration. Thinning implies selective removal of trees to allow the growth of others, and in the end of rotation, more trees are removed. The third alternative is management only activated sparingly (50-100 years) following close-to-nature approaches.

\section{Agent sub-model: landowner behavior}

Forest owners are identified as primary agents of forest ecosystem services provision (Sotirov et al. 2019). The literature on private forest owners shows that their decision-making process with regard to the management of their forests is not only based on economic factors, but also includes feelings of moral responsibility and pride (Oliva et al. 2016). Moreover, others have argued that the intention of forest owners is to do "good" in their forests (Domínguez and Shannon 2011). Several scholars suggest the need to tailor policy design to the forest owner character type (Boon et al. 2004, Layton and Siikamäki 2009, Primmer et al. 2014) as a factor more relevant than financial incentives (Serbruyns and Luyssaert 2006). The importance of identifying forest owner typologies for the effectiveness of PES has been studied by Ferraro (2008), who recommends collecting information on observable landowner attributes before implementing the policy. At the same time, forest owners have long planning intervals that should be accounted for in the design of any policy. 
Table 1. Optimal design characteristics in payments for ecosystem services (PES) schemes, as discussed in the literature and workshop results.

\begin{tabular}{|c|c|c|c|}
\hline Design & Explanation and reason & Literature & Workshop results \\
\hline $\begin{array}{l}\text { Recurrent } \\
\text { payments over } \\
\text { a long-term } \\
\text { period }\end{array}$ & $\begin{array}{l}\text { Several payments rather than a } \\
\text { one-off payment helps } \\
\text { landowners to better identify the } \\
\text { ecosystem services provided, } \\
\text { which in turn increases } \\
\text { willingness to accept. }\end{array}$ & 1 & $\begin{array}{l}\text { Indirect payments are preferred over direct payments. Direct } \\
\text { payments cause fiscal issues for forest owners and indirect payments } \\
\text { (funds managed by the intermediary) can be used to cover the costs } \\
\text { of the management change. Payments should be both monetary and } \\
\text { in-kind, the latter in the form of support from the forest agency in } \\
\text { terms of technical knowledge and expertise. The payments should be } \\
\text { linked to the change in management, thus, recurrent payments every } \\
\text { time forests are managed, rather than a one-off payment, appears to } \\
\text { be the preferred option. }\end{array}$ \\
\hline
\end{tabular}

experienced

lead is related to trust, expertise, and

intermediary

the activation of local networks

7,15

or PES support. It also reduces

inefficiency related to

asymmetric information inherent in PES schemes.

Targeting of Output-based designs with one

one clear target or goal seem to

environmental perform better than schemes goal that bundle a multitude of ecosystem services.

Financial coverage Payments that are equal to or surpasses cost management change seem of management necessary to ensure landowners' change Spatially explicit willingness to accept. The PES design should consider the characteristics of the area, including types of landowners and land ownership.
$2,3,4,5$, A trusted intermediary should monitor the management to improve water quality. This actor should not be the same as the suggested local intermediary, a local independent agency. The latter would have responsibilities for funding management and coordination with forest owner associations as well as the forest regional authority.

$1,4,5,6$, The targeting of one environmental goal was not explicitly 12, 13, addressed, but it was implicit, provided the woodland-for-water PES 16 scheme was already the focus of discussion and this addressed the benefits of certain forest management actions for water quality/ quantity.

$7,11,14$ The cost of this type of management was assessed at $1500 €$ per ha and the assumption in the workshop was that the financial compensation would cover the additionality of this amount to current management practices.

4, 8, 10 Communication plans should be designed to explain the benefits of the PES schemes to land owners of the area as well as the general public to avoid conflict brought about by differences in points of view between urban and rural areas. This aspect was proposed by forest owners and local authorities on the basis of concerns that the targeted stakeholders would otherwise be more likely to continue the tendency toward land abandonment in the study area.

Literature Cited ${ }^{1}$ Chen et al. 2014; ${ }^{2}$ Toderi et al. 2017; ${ }^{3}$ Schomers et al. $2015 ;{ }^{4}$ Meyer et al. $2015 ;{ }^{5}$ Sattler et al. 2013;

${ }^{6}$ Schleyer and Plieninger 2011; ${ }^{7}$ Vedel et al. 2015; ${ }^{8}$ Lundberg et al. 2018; ${ }^{9}$ Dedeurwaerdere et al. 2015; ${ }^{10}$ Sheremet et al. 2018; ${ }^{11}$ Mäntymaa et al. 2018; ${ }^{12}$ Reed et al. 2017; ${ }^{13}$ Horne 2006; ${ }^{14}$ Bösch et al. 2018; ${ }^{15}$ Abildtrup et al. 2012; ${ }^{16}$ Primmer et al. 2014.

Forest owner behavioral models cluster agents in six different categories: optimizers, traditionalists, maximizers, passives, multi-functionalists, and environmentalists (Sotirov et al. 2019). These categories are theory led but have been contrasted with empirical evidence (Deuffic et al. 2018) and matched with other established categories from case studies around Europe (see Table 3 in Sotirov et al. 2019). Optimizers and maximizers are characterized by intensive forest-oriented forestry, generally large-scale, with or without respect for rules. The next four categories are rather associated with small-scale forest owners. Traditionalists are related to family ownerships that maintain traditional values. Passives barely manage their forests because of a preference for an urban lifestyle. Finally, multi-functionalists and environmentalists partake in either medium to low intensity management, with a focus on ecosystem services including wood production in the first and close-to-nature approaches in the latter. They generally comply with rules if they perceive these to be aligned with their values. These assumptions are similar to the work of Layton and Siikamäki (2009). Other references support the idea that some agents always participate, whereas others will not, independent of any factor (Boon et al. 2004, Hogl et al. 2005, Hujala et al. 2007, Ní Dhubháin et al. 2007, Makkonen et al. 2015).

From data for the area, we know the number of owners (1098), the approximate size of their forests, as well as if they have a forest management plan (FMP), which are technical documents documenting the activities that will be conducted during a certain period (Brukas and Sallnäs 2012). The base scenario for our model begins with 1000 forest owners and no optimizers or maximizers, because they are not present in our case (Fletas et al. 2012, and data from the 2010 register). Among them, we distributed a random number of hectares, which can be between 
1 and $25 \mathrm{ha}$, as observed in the region and representative of scenarios of property atomization as the main regime in Catalonia (Icea 2019). The distribution is random and changes every time the model is run. From expert knowledge from the area, it is known that $40 \%$ of owners have an FMP and $60 \%$ do not. From the former, we divide $20 \%$ multi-functionalists and $20 \%$ traditionalists, because these categories generally tend to have a higher level of engagement in terms of forest practices, including, e.g., contact with forest authorities or request of subsidies. From areas without an FMP, a majority enter into the category of passives $(40 \%)$ and some are environmentalists $(20 \%)$, who held beliefs of passive management as a way of nature conservation. In the model interface, these distributions can be changed, but our results are based on the references. The actual distribution of forest owner categories for the area is unknown. The experts, who were from the forest administration in charge of private forests (CPF) in partnership with the researchers conducting the EUfunded project ${ }^{[8]}$, agreed to the plausibility of the final distribution in global terms, of percentage of passives $(40 \%)$ and actives $(60 \%)$. Discussions with these experts were held once the second workshop officially concluded and the main outcomes were being summarized.

In the model, agents will not make errors in their decisions: they will always follow the style of management aligned to their values. To bring about agent compliance, the compensation should generally cover the cost of the actual change in behavior nonetheless. Finally, one policy scenario simulates the concept of attrition, by which the policy design demotivates participation in the scheme across the years.

\section{Ecological sub-model: woodland-for-water under climate variability}

For the ecological model we used two sources of information: GIS and the outputs of the model GOTILWA+ (Growth Of Trees Is Limited by WAter), developed and applied to study responses of different forest types to water availability in Mediterranean areas, but also applicable to temperate and boreal regions (C. Gracia, S. Sabaté, and A. Sánchez, 2003, unpublished manuscript; D. Nadal-Sala, S. Sabaté, C. Gracia, and CPF, 2014, unpublished manuscript). In the context of an EU-funded project, GOTILWA + was implemented using the ORGEST guides for certain tree species (Pinus halepensis, Quercus ilex, Pinus nigra, Pinus sylvestis, and Quercus humilis), which are those present in our case study, with Pinus nigra at $40 \%$ of the total forested area and $Q$. ilex and Q. humilis at 26\%, jointly following (FTiP 2003). Input data required to run the model ranges from climate change scenarios based on the Intergovernmental Panel on Climate Change, quality of the seasonality, meteorology, and soil quality. From GOTILWA + we used its output as data for our sub-model, matched to the characteristics of our case study ${ }^{[9]}$. This output data includes percentage of evapotranspiration (ET) and runoff by tree species and impact of management on runoff and drought (D. Nadal-Sala, S. Sabaté, C. Gracia, and CPF, 2014, unpublished manuscript). Our model does not include seasonality but it does include the expected decrease in rainfall following known variation (FTiP 2003).

In the SESPES model, we grouped trees in two main species, conifers (Pinus halepensis, Pinus nigra, Pinus sylvestis) and broadleaf ( $Q$. ilex and $Q$. humilis), and each underwent different physiological processes. These were grouped and distributed from raster data to develop a spatially explicit model using the GIS extension. The information contained is topography (altitude and slope), percentage of forested area, and the types of land cover in these areas. In our model, the total number of 32508.8 pixels from the interface is equal to $270 \mathrm{~km}^{2}$, where each pixel in the map is equivalent to $0.8 \mathrm{ha}$. The total forested area is $281.2 \mathrm{~km}^{2}$ and, from this, $\sim 50$ ha are shrubland. Among the forest owners, the model distributed an average of 260 ha in each run. This base scenario simulates the situation in the region with a majority of forest owners $(95.2 \%)$ owning $<25$ ha (Icea 2019). Table 2 shows the data used for the model and sources by sub-model.

Model parameters were chosen with the use of expert assessment or empirical data from the area. The distribution of forest owner categories was the only data for which we did not have validation via secondary prediction, and we used categorical calibration by observing changes in the number of managed ha through small changes in the distribution of forest owner typologies ${ }^{[10]}$ (Railsback and Grimm 2020).

The simulations represented each of the effects of different PES policy designs on the behavior of forest owners. As results, we present four scenarios:

1. Short-term, by which all best practices are activated and each forest owner proceeds with their own style of management aligned to the values as presented in the social sub-model;

2. Attrition, by which every certain number of years the number of forest owners participating is reduced because of no recurrent payments and loss of motivation;

3. Long-term, by which two ES goals are pursued simultaneously and trade-offs on management imply that forest owners only intervene in the forest under long periods; and,

4. Base scenario, with only the ecological sub-system, equal to a policy that does not ensure financial coverage to forest owners.

Table 3 and Figure 2 map and illustrate the selected scenarios visà-vis the simulated owner behavior.

Fig. 2. Interactions between agent behavior and policy design: opted for scenarios.

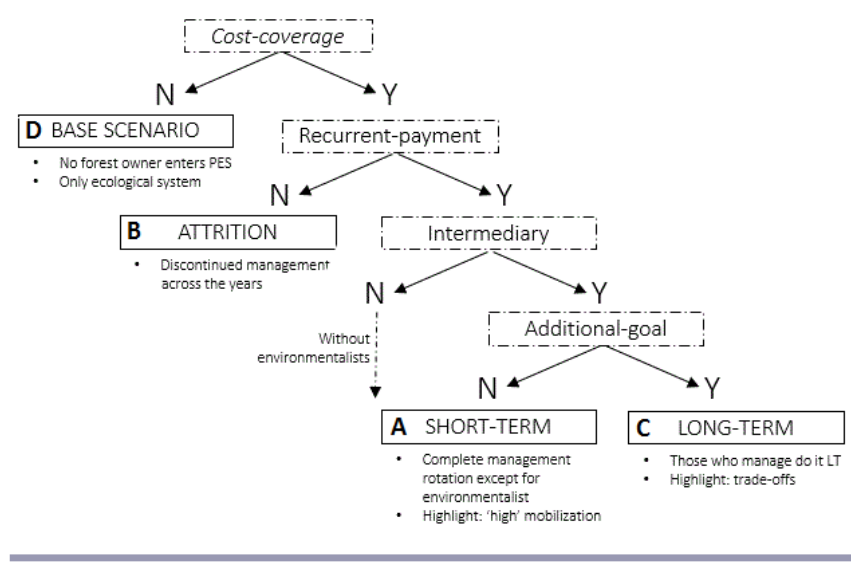


Table 2. Input data by sub-model.

\begin{tabular}{|c|c|c|}
\hline Data & Base values & Source \\
\hline \multicolumn{3}{|l|}{ Ecological } \\
\hline Average annual precipitation & $575 \mathrm{~mm} / \mathrm{y}$ & Management Plan of Rialb \\
\hline Annual change & $-0.2 \% / y$ & \\
\hline ET by species and change & & GOTILWA+ \\
\hline Black pine & $65-85 \%,+5 \% / 150 y$ & \\
\hline Oak & $85-92 \%,+5 \% / 150 y$ & \\
\hline \multicolumn{3}{|l|}{ Run-off by species and change } \\
\hline Black pine & $15-35 \%,-5 \% / 150 y$ & \\
\hline Oak & $8-15 \%,-5 \% / 150 y$ & \\
\hline \multicolumn{3}{|l|}{ Impact of management } \\
\hline On blue water, black pine & $0-10 \%$ & \\
\hline On blue water, oak & $0-5 \%$ & \\
\hline Land cover (see Fig.1) & $\begin{array}{l}\text { Pinus halepensis, } P \text {. nigra, } P \text {. sylvestis as conifers; } \\
\text { Quercus ilex, } Q \text {. humilis as broadleaf }\end{array}$ & GIS data \\
\hline Tree age & $\begin{array}{l}\text { Trees receive a (random) age between } 20-150 / 100 \\
\text { years depending on the specie. }\end{array}$ & - \\
\hline \multicolumn{3}{|c|}{$e^{2}$} \\
\hline Property type & $93 \%$ private & Management Plan of Rialb \\
\hline Number of owners & 1000 & \\
\hline Number of management plans & $10 \%$ & \\
\hline Number of $\mathrm{km}^{2}$ & $280 \mathrm{~km}^{2} / 350 \mathrm{~km}^{2}$ & \\
\hline Typology of forest owner & Behavioral models & (Sotirov et al. 2017) \\
\hline \multicolumn{3}{|l|}{ Structural } \\
\hline \multirow[t]{3}{*}{ Recurrent payments } & ST + LT Management with attrition & ORGEST guides \\
\hline & & Short-term ST: every $15 / 35$ \\
\hline & & Long-term LT: every 50/100 \\
\hline Presence of intermediary & ST management / no management & \\
\hline $\mathrm{N}$ environmental goals & LT management & \\
\hline Financial coverage & ST + LT Management / No management & \\
\hline
\end{tabular}

We ran each scenario 100 times $^{[11]}$ for a period of 150 years (each tick equivalent to one year) because of the stochastic elements of the model, which are the distribution of forest owners and their properties, including dimensions of these properties, as well as the reduction in water use efficiency rate from management. The time period incorporated at least two generations of forest owners (Schouten et al. 2013) and thus the assumption that the second generation will maintain the decisions taken by their precedents. To improve running efficiency, we followed the recommendations from Railsback et al. (2017).

\section{Model verification and validation}

Model accuracy was assessed by verification, replication, and validation. Verification is the fit between the conceptual model and the implemented model. Replication is the capacity of other researchers to implement the conceptual model. Finally, validation implies contrasting the model results with alternative predictions, either from the literature or empirical data (see, e.g., Wilensky and Rand 2015). For model verification, we introduced unit tests for the set-up of the model. One is applied to the spatially explicit model to ensure that all land-uses represent the original GIS data. The second tests for the even distribution of ha per forest owner. In both cases, the interface displays an error message to users in the case that either of the two conditions encounters an error. Additionally, we completed the code with pseudo-code, a.k.a. explanations alongside the code of what the model is expected to perform following the conceptual model. To enable model replication, we provide the model and ODD protocol online ${ }^{[12]}$.

For model validation, we made use of empirical data. This involved testing our predictions in relation to number of managed hectares for the total period as well as the estimated average rates of water use efficiency at the end of the 150-year mark. For the first, we used IFN (National Forest Inventory) data and available mapping from the CPF. According to this data, and with the criteria of slope, accessibility, and state of the forest, the potential area to act would be between 3300 hectares (cutting only where there is more timber, minimal but profitable cutting) and 12,000 hectares (cutting where there is something to cut, seeking the maximum benefit in water). The cutting actions currently planned in the set of management plans in the area affect 5760 hectares. With these three data points we compared them vis-à-vis our model outputs. For the water use efficiency validation, we used simulated data for the case study generated in the context of the EU-funded project. The study evaluated the gains in blue water in a single point action that extracted $30 \%$ of the basal area (i.e., thinning of $\sim 30 \%$ of trees). The simulation is done with the MEDFATE model (De Cáceres et al. 2021), which does not take into account growth (such as GOTILWA) but it is more realistic 
Table 3. Forest owner behavior responses to policy design.

\begin{tabular}{|c|c|c|c|c|}
\hline Typology & Acronym & Values & Management & Policy design \\
\hline Multi-functionalist & MFU & $\begin{array}{l}\text { ES provision incl. } \\
\text { timber }\end{array}$ & $\begin{array}{l}\text { Thinning short-term } \\
(15 / 35 \mathrm{y}), 30 \% \text { of owned } \\
\text { territory, and end of } \\
\text { rotation cutting }(50 / 100 \mathrm{y}) \text {. }\end{array}$ & $\begin{array}{l}\text { Financial coverage; one ES goal, } \\
\text { otherwise they perform only long-term } \\
\text { (due to trade-offs); intermediary does } \\
\text { not affect them: they manage; } \\
\text { recurrent payments, otherwise the } \\
\text { number of active MF decreases across } \\
\text { years. }\end{array}$ \\
\hline Environmentalist & ENV & $\begin{array}{l}\text { Close-to-nature } \\
\text { approach }\end{array}$ & $\begin{array}{l}\text { Thinning long-term } \\
\text { rotations }(50 / 100 y)(15 \%)\end{array}$ & $\begin{array}{l}\text { Financial coverage; number of goals } \\
\text { do not affect them (manage LT); if } \\
\text { absent, intermediary they do not } \\
\text { manage. Recurrent payments, } \\
\text { otherwise the number of active ENV } \\
\text { decreases across years. }\end{array}$ \\
\hline Traditionalist & TRA & $\begin{array}{l}\text { Family/traditional } \\
\text { practices }\end{array}$ & Same as MFU & $\begin{array}{l}\text { TRA follow the actions from their } \\
\text { direct neighbors (a.k.a. their } \\
\text { community). }\end{array}$ \\
\hline Passive & PAS & Urban lifestyle & None & Irresponsive \\
\hline
\end{tabular}

because it includes competition between trees and shrub and the results were obtained from data from our case study ( 80 plots in the IFN). From this data, the average annual gain was calculated assuming vegetation growth will be reduced every $15-20$ years, as implemented in our model (thinning turns and $30 \%$ of thinning for MFU and TRA). The average gain in water use efficiency according to these calculations is $7 \%$ in conifers and $3.2 \%$ in broadleaves at the 150 -year mark.

\section{RESULTS}

\section{Policy and social sub-models}

The social sub-model starts with 1000 forest owners with each of the small-scale categories with a $20 \%$ presence with the exception of passives with $40 \%$. The model randomly distributes "territories" to each group, and thus the number of ha owned by individual and group varies at each run, as well as its location. This has effects on the actions taken by traditionalists, whose management is influenced by the actions of their neighbors ${ }^{[13]}$ rather than stimulated by the policy design. Whereas location could not be tracked during the model runs, the model interface shows the amount of ha allocated to each of the forest owner types at initiation. Table 4 shows the average number of distributed hectares (ha) by forest owner category.

Multi-functionalists (MFU) manage for the short-term under (A) short-term and (B) attribution, and (C) long-term rotation (see Fig. 2, for the policy scenarios). Environmentalists (ENV) manage only long-term, and we can observe from the 150-year mark how these two forest owner categories display similar percentages in scenario C. Traditionalists (TRA) show similar outputs in each of the scenarios. Table 4 also shows in the last column the amount of forested mass at the end of the period, with a decrease up to $10 \mathrm{~km}^{2}$ in the base scenario (D), which displays the evolution of the area without the presence of the PES scheme (see Fig. 3). This area is assumed to be degraded.

Figure 4 shows the evolution of managed forests across the 150 years. For the first two scenarios MFU show almost four times more the output of the active peers, and ENV and TRA show a very close-by pattern. Only in scenario D, all three groups show similar distinguishable paths. Provided TRA is triggered by the activity of their neighbors, their managed percentages at the 150year mark are always below that of the peers even under different management styles between them, short-term and ENV longterm. Another interesting result is the development of policy scenario B considered to trigger attrition. Attrition implies that some forest owners participating in the scheme stop being interested and abandon the policy. In spite of this, the final outputs relative to the short-term policy design are very similar. This implies that the impact of attrition is not linear and appears to be low. Under increasing levels of attrition, thus, the intermediaries of the scheme could intervene by improving communication (external change). Additionally, given that the differences between A and B are recurrent payment vs. one-time payment at the end of the management activity, it would be possible for the intermediary to also modify this aspect to maintain the motivation of the participants. Additional characteristics of both policies are the presence of an intermediary, as suggested, as well as one ecosystem (water and possibly timber, but not water and fire) and the coverage of the costs of the change in management from traditional to additionally improving water bodies.

Noticing the differences between the 25-year mark, conceptualized as the first generation of targeted forest owners (Schouten et al. 2013), and the end of the period also shows important results. The overall percentage of managed forests in both the short-term and the attrition policy design are similar to the percentage reached in policy $\mathrm{C}$ at the 150 -year mark. The fact that PES participants observe benefits from their participation in the scheme has been mentioned as a motivational factor to keep the policy. At the same time, it has very important implications for the effects on the ecosystem. In summary, policy A and B established a link between the social goal (active stakeholders) and the ecological goal (water efficiency) more clearly then the long-term design. 
Fig. 3. Model interface as implemented in Netlogo.
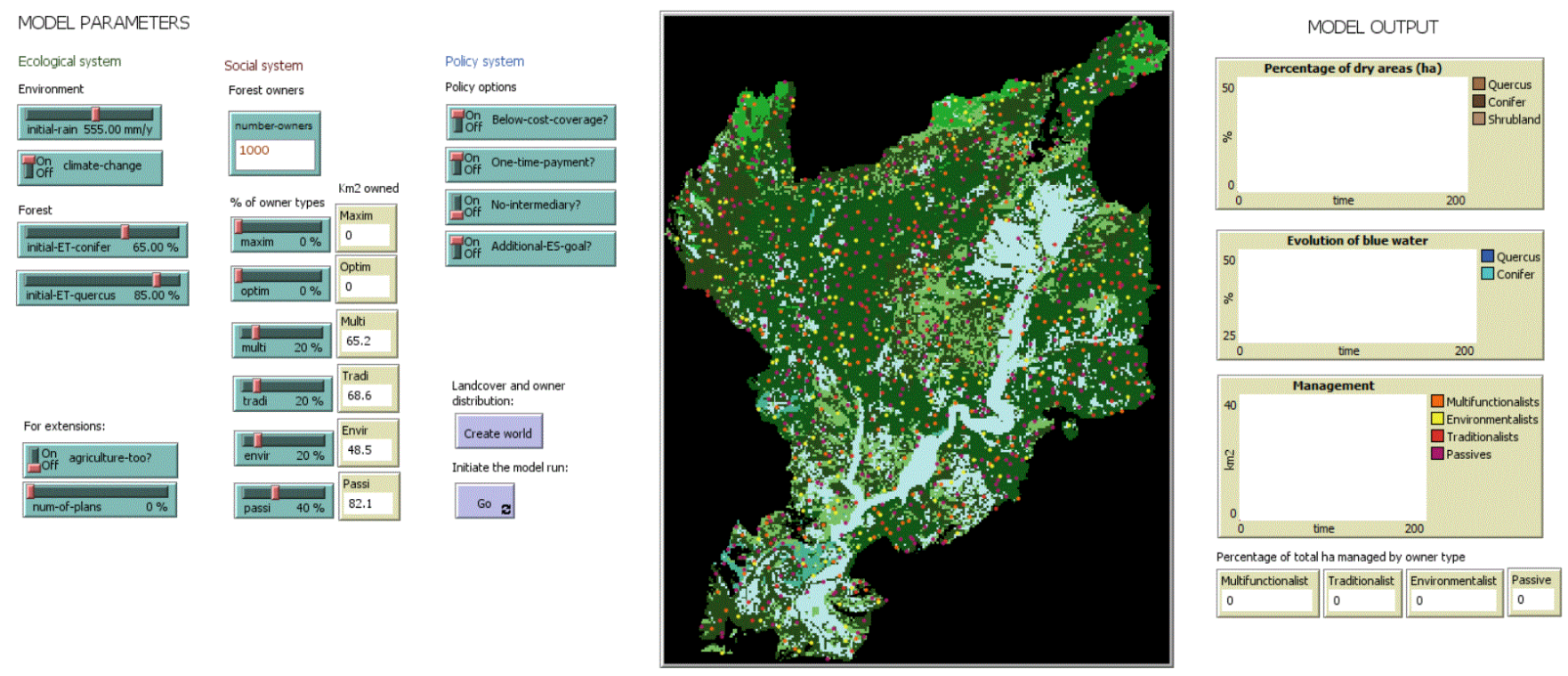

Fig. 4. Management scenarios following policy design schemes (A-C), average of 100 runs.
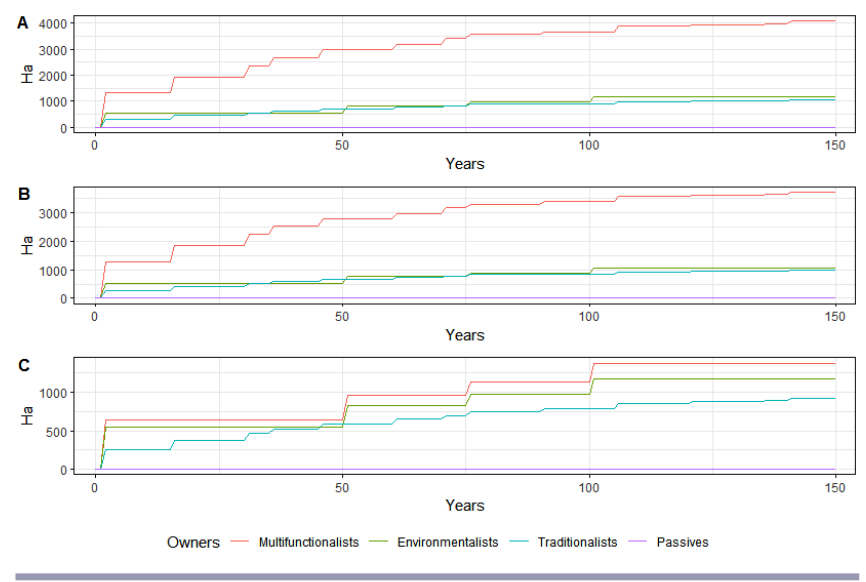

Policy and ecological model

The ecological model varies across the years, taking into account the effects of climate change. The two main simulated effects are a reduction in precipitation and an increase in the amount of water needed by forest stands. We added the effects of drought, an event that occurs with the decrease in precipitation and during which older trees show signs of stress either through dieback or converting into shrubland. The rate at which this occurs increases with the decrease in rainfall.

Figure 5 displays the evolution of the forest under the different policy simulations. The base scenario reflects the abovementioned ecological circumstances and parallels the policy in which the cost of management change is not covered. The lack of financial support would impede forest owners to engage in a

change in their management and thus the ecosystem evolves without the effects of a policy (D). The map in (C) represents the effects of the policy when it triggers long-term instead of shortterm management (A), and the third scenario implies the context of attrition, but which displays similar results as commented above. These illustrations show the endpoint after 150 years. Brown dots simulate tree cover under stress, and light green dots, parcels that have been managed. In scenario A, the territories of some of the forest owners can be distinguished. Tree stress is in spite of management present in all scenarios, and it does not differ much across scenarios: with a simulated $8.7 \mathrm{~km}^{2}$ loss in scenario A and $11.8 \mathrm{~km}^{2}$ in scenario D.

Fig. 5. Illustration of the area under different management scenarios, 100 years.

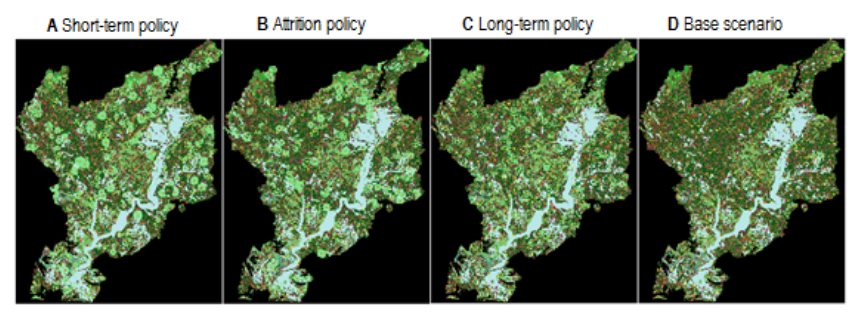

The final output from the model is the expected average of blue water percentage across forest tree species (Fig. 6). Blue water is defined as the percentage of water after tree consumption, which corresponds to the run-off and drainage (D. Nadal-Sala, S. Sabaté, C. Gracia, and CPF, 2014, unpublished manuscript). These begin at an average of $35 \%$ for conifers and $15 \%$ for broadleaf and decrease by $0.03 \%$ each year. Management is expected to improve the ratio by $0-10 \%$ and we simulated the effects whereby, when managed, tree stands would demonstrate an improvement of between 0 and $10 \%$. 
Table 4. Distribution of ha by forest owner category and policy scenario. average of 100 runs.

\begin{tabular}{|c|c|c|c|c|c|c|c|c|c|c|c|}
\hline \multirow[b]{2}{*}{ Year } & \multirow[b]{2}{*}{ Policy } & \multicolumn{2}{|c|}{$\begin{array}{c}\text { Multi- } \\
\text { functionalists }\end{array}$} & \multicolumn{2}{|c|}{ Environmentalists } & \multicolumn{2}{|c|}{ Traditionalists } & \multicolumn{2}{|c|}{ Passives } & \multirow{2}{*}{$\frac{\text { TOTAL }}{\text { ha }}$} & \multirow{2}{*}{$\frac{\text { Forest }}{\mathrm{Km}^{2}}$} \\
\hline & & $\begin{array}{l}\text { Total } \\
\text { (ha) }\end{array}$ & $\begin{array}{c}\text { Managed } \\
(\%) \\
\end{array}$ & $\begin{array}{l}\text { Total } \\
\text { (ha) }\end{array}$ & $\begin{array}{c}\text { Managed } \\
(\%) \\
\end{array}$ & $\begin{array}{l}\text { Total } \\
\text { (ha) }\end{array}$ & $\begin{array}{c}\text { Managed } \\
(\%) \\
\end{array}$ & $\begin{array}{l}\text { Total } \\
\text { (ha) }\end{array}$ & $\begin{array}{c}\text { Managed } \\
(\%) \\
\end{array}$ & & \\
\hline 1 & A Short & 6031.6 & 22.2 & 5354.5 & 10.2 & 6733.9 & 4.4 & 8361.3 & - & 26481.3 & 276.6 \\
\hline 50 & & & 49.4 & & 10.2 & & 10.5 & & - & & 273.7 \\
\hline 100 & & & 60.8 & & 18.3 & & 13.6 & & - & & 269.2 \\
\hline 150 & & & 67.7 & & 22.2 & & 15.6 & & - & & 268.0 \\
\hline 1 & B Attrition & 6038.3 & 21.0 & 5213.8 & 9.8 & 6792.4 & 4.1 & 8342.0 & - & 26386.6 & 276.6 \\
\hline 50 & & & 46.2 & & 9.8 & & 9.8 & & - & & 273.7 \\
\hline 100 & & & 56.1 & & 17.0 & & 12.7 & & - & & 269.0 \\
\hline 150 & & & 61.6 & & 20.3 & & 14.5 & & - & & 267.7 \\
\hline 1 & C Long & 6075.8 & 10.4 & 5276.1 & 10.3 & 6781.3 & 3.7 & 8338.0 & - & 26471.2 & 276.6 \\
\hline 50 & & & 10.4 & & 10.3 & & 8.6 & & - & & 273.1 \\
\hline 100 & & & 18.7 & & 18.4 & & 11.5 & & - & & 268.0 \\
\hline 150 & & & 22.6 & & 22.2 & & 13.5 & & - & & 266.5 \\
\hline 1 & $\mathrm{D}$ & 6002.2 & - & 5269.0 & - & 6667.8 & - & 8450.7 & - & 26389.8 & 276.6 \\
\hline 50 & Ecological & & - & & - & & - & & - & & 272.7 \\
\hline 100 & & & - & & - & & - & & - & & 266.7 \\
\hline 150 & & & - & & - & & - & & - & & 264.8 \\
\hline
\end{tabular}

Fig. 6. Average, minimum, and maximum blue water $(\%)$ by tree species at the 150-year mark. Av. 100 runs

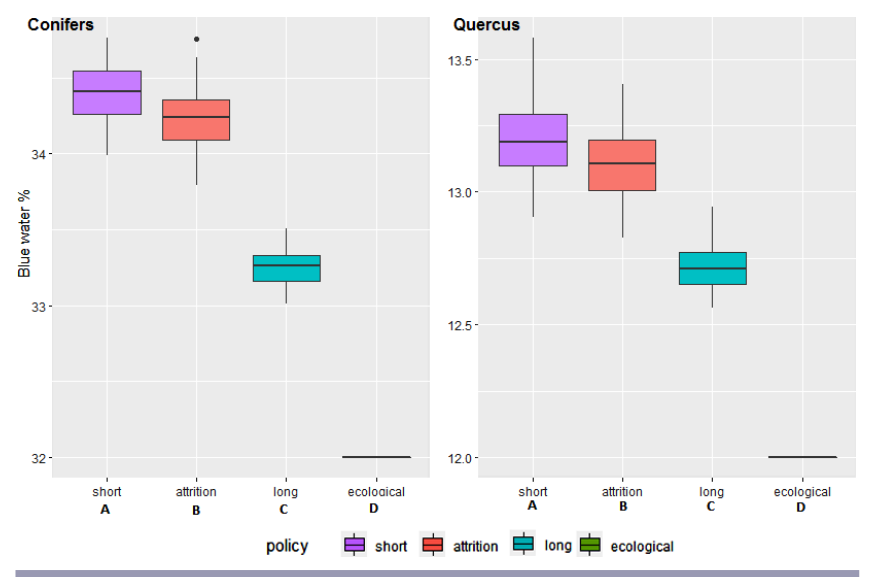

Results show that without any type of management, in 100 years, there is a 3-point reduction in blue water, whereas under all other types of policy design, this rate is improved, despite all of them being slightly less than the initial base scenario. The marginal difference between scenarios is minimal, but scenarios $\mathrm{A}$ and $\mathrm{B}$ show similar rates to the ones at the year-mark 0 (model initiation). Thus, with regard the water use efficiency output expected from the presence of the PES policy, the types of management do not show much difference among each other despite significant differences in the amount of managed stands.

\section{Validation of the model outputs}

Our main two outputs of the model are amount of managed forests and the improvement in the blue water percentage relative to green water. For amount of managed forests, the total managed hectares for policy B and C are very similar to the minimum and planned amount. The minimum amount of management in the area is estimated at 3300 ha taking into account only minimal cutting. Our policy scenario $\mathrm{C}$ obtained an average across runs of 3461.6 ha, which is a scenario accounting for close-to-nature management rotations characteristic of long-term interventions. Policy scenario B displayed a total output of 5760.4 managed ha. This output is casually exact to the planned number of ha that are planned to be managed in the Rialb river basin, following the information from the FMP, also estimated at 5760. This amount has a difference of $\sim 560$ ha to scenario A output set at 6321.7 ha on average. We thus consider this output realistic in terms of potential expected amount of forest management in the area. Finally, in relation to this, the maximum capacity of the forest is set at 12,000 ha which would imply cutting independently of the profitability and obtaining the maximum gains in water use efficiency. These scenarios could be reached if any of the forest owners acted with similar patterns as the MFU. However, in the context of our case study representing a Mediterranean area with low profitability of forest products and land abandonment is a very unrealistic scenario without public intervention and investment.

The second step of the validation implies the water use efficiency outputs. In this case, there was a parallel study performed to draw estimates of the $\%$ of blue water at the 150-year mark with a similar management regimen as performed in our model by MFU and TRA. This study showed a $7 \%$ (blue water ratio relative to green water at $28 \%$ ) improvement in the blue water percentage in conifers and $3.2 \%(11.8 \%)$ in broadleaf. Our results for broadleaf are very similar, with a difference of $-0.7,-0.5$, and 0.2 respectively in scenarios A, B, and C. However, the differences are of up to -6 points in the case of conifers $(-5.9 ;-5.7 ;-4.6)$. These differences could be explained by the fact that water use efficiency was a random process happening each time there was management: the 
range for conifers was $0-10 \%$ improve and for $0-5 \%$ for broadleaves, following the results from GOTILWA, and thus, the possible variance within the latter was smaller than in the case of the former. With these results we cannot validate our results in terms of the output for the water use efficiency gains.

\section{DISCUSSION AND CONCLUSION}

There is a gap between policy implementation and agent compliance. Policy design is expected to shorten this gap, by triggering different behavioral responses in the targeted agents. In a recent EU survey, these direct changes in behavior were signaled as the key factor influencing the effectiveness of woodland-for-water schemes (Báliková et al. 2020). For these reasons, PES policy design has generated an intense debate in the literature (Wunder et al. 2018, 2020, Wells et al. 2020). In this study, we have considered additionally the context of land abandonment and management dynamics with a Mediterranean case study.

Based on an EU-based PES literature review, we designed a spatially explicit agent based model to observe how such structural factors would affect the decisions of forest owners and influence the ecosystem. Results show that at the 25-year mark, which includes the assumption that the first generation of targeted forest owners will still be present, the management outputs of policy designs that fostered recurrent interventions in the forest are the same as those expected at the 150-year mark for other policy designs, particularly those that triggered long-term management. The considered optimal policy design included repeated payments, the presence of a local intermediary, and the targeting of one ecosystem goal. Long-term policy designs included the targeting of multiple ecosystem goals such as water protection and fire risk management. At the ecological level, nonetheless, the several scenarios showed similar outputs in terms of water use efficiency gains, which could imply the necessity for more aggressive forms of intervention that some stakeholders may always reject to implement because of contrary values of what "optimal values" are significant. Other studies performed in our area study and using the same management approach as the one simulated in the optimal scenario, nonetheless, showed significant differences in the water use efficiency. Our model could thus be underestimating the impact of the management on water.

Our findings additionally suggest that PES that include the figure of the intermediary could be beneficial for areas in which urbanrural dynamics have driven land abandonment. The choice of the intermediary is seen as key because it is expected to generate trust among targeted agents, some of whom would not otherwise adhere to the policy. In our model, the figure of the intermediary ensured that the first generation of targeted forest owners would be able to see changes in the system from the change in behavior. The literature has already highlighted that the intermediary is a key actor because it generates trust among stakeholders and can improve the likelihood that targeted agents will voluntarily enter the scheme (Báliková et al. 2020). This supports the literature on PES schemes that categorizes it as a hybrid system consisting of both market- and network-based modes of governance (PahlWostl 2015). This is demonstrated in the fact that financial support is not sufficient by itself, but requires collaborative structures among stakeholders (from forest owners to authorities) to ensure that the PES policy influences the targeted social- ecological system. This intermediary could add communication policies to its repertoire to have better engagement with forest owners and find synergies between the values and preferences of stakeholders and the goals of the PES policy, as the results of the workshop also highlighted. Innovating in PES policy design and allowing for different forms of compliance has also been suggested by PES scholars as possible means of increasing compliance (Jack et al. 2008). Based on empirical studies on forest owners, some scholars suggest these communication activities should also be designed differently depending on recipients' characteristics (Kuipers et al. 2013).

The model accounted also for the presence of different landowner typologies, which responded differently to the design of the policy. Provided this study's and similar findings in related literature (Boon et al. 2004, Serbruyns and Luyssaert 2006, Ferranti et al. 2017), taking into account the characteristics of landowners and their socioeconomic context seems of key importance. This stakeholder network mapping would include information on the intensity of their management and engagement within the landowner community, main values about the ecological, recreational, and production views on forests (Nordlund and Westin 2011), and the main activities performed in them. This information could help assess the expected compliance and even their willingness to accept a conservation policy. In our case, the distribution of forest owner typologies was the primary assumption. Whereas we based the initial distribution in expert knowledge from the area, there are some discrepancies that we consider as limitations for our study. On the one hand, for the model we assumed forest owners without management plans were either passives or environmentalists, and forest owners with management plans were active categories. Moreover, we assumed that multi-functionalists would always engage in the PES scheme. These are non-validated assumptions, and for this reason we understand that either including the use of surveys or extending the participatory approach to the ABM at several points of model development would be of great benefit for these type of studies.

In Europe, financial incentives for ES provisions other than provisioning services (e.g., timber) are more present in the agricultural sector than in the forest sector (Bösch et al. 2018). Nevertheless, there is increasing interest in implementing such schemes to support forest management, with the expectation that these would "provide significant benefits to a locality, community or industry" (Capodaglio and Callegari 2018), even if they were implemented in limited local areas. Innovating in policy design for the management of complex social-ecological systems is proposed by proponents of adaptive management and comanagement approaches to governance (Armitage et al. 2009). In such schemes, building trust among stakeholders as well as continued monitoring of the implemented policies are also emphasized. In line with the results of our study, we consider this form of governance to be compatible with PES.

To conclude, an extension of the model could tap into the possibility for an innovative approach to PES design including differences depending on the targeted stakeholders, instead of being, as we have implied in this article, one-size-fits-all. The exploration of this possibility could yield further contributions to the debate on PES design. An alternative extension could be the incorporation of the "willingness to pay" (Primmer et al. 2014, 
Mäntymaa et al. 2018). Generally, PES schemes consider the involvement of private benefiting actors, such as tourism companies or other local providers. Involvement of these stakeholders in a participatory ABM could yield important insights into effective PES design.

${ }^{[1]}$ PES can be defined as "(1) voluntary transactions (2) between service users (3) and service providers (4) that are conditional on agreed rules of natural resource management (5) for generating offsite services" (Wunder 2015:241). This definition was adapted from Wunder (2005) in response to critiques and implementation experiences. For more on PES definitions see Sattler and Matzdorf (2013).

${ }^{[2]}$ In Europe, compensation for ecological services from natural resources started in the 1970s with the agri-environmental schemes (AES) under the Common Agriculture Policy, as a policy closely resembling PES (Schomers and Matzdorf 2013).

${ }^{[3]}$ The ABM, designed with Netlogo (Wilensky 1999), can be downloaded from the Netlogo Modeling Commons website as well as COMSES network, to be found under the name: SESPES: socio-ecological systems and payment for ecosystem services model.

Netlogo: http://modelingcommons.org/browse/one model/6398 COMSES: https://www.comses.net/codebases/1blac7b5-8015-4003a838-2180586b8083/releases/1.1.0/

${ }^{[4]}$ Data obtained from the register of the forest administration, Centre de la Propietat Forestal, in charge of private forests.

${ }^{[5]}$ Reference to the ODD protocol from our model in: Baulenas, E. (2020, 20 December). "SESPES: socio-ecological systems and payment for ecosystem services model" (Version 1.1.0). CoMSES Computational Model Library. Retrieved from: https://www. comses.net/codebases/1b1ac7b5-8015-4003-a838-2180586b8083/ releases $/ 1.1 .0 /$

${ }^{[6]}$ Our understanding of effect on the ecosystem is informed by the literature on adaptive governance, which describes it as "restoring, sustaining, and developing the capacity of ecosystems to generate essential services." (Olsson et al. 2006).

${ }^{[7]}$ The final report can be shared upon request. A press report from the meeting can be found in the project website (accessed December 2020): https://sincereforests.eu/rialb-2021-forests-andwater2l

${ }^{[8]}$ These same experts are involved in supporting the creation of a forest association in the area, and thus are in contact with the local community of forest owners.

${ }^{[9]}$ GOTILWA+ provides an average of all management made in a specific forest over 150 years (approx. 10 clearings), starting in 2000.

${ }^{[10]}$ We augmented or decreased active and passive forest owner typologies by $10 \%$. Results show that a $10 \%$ increase in the number of active forest owner typologies has a greater effect on the total number of managed ha than the effect that it has on the contrary scenario of greater number of passives. However, these changes are minimal and they are inside the parameters given by the number of expected management.

${ }^{[11]}$ We base this number as an often used standard in ABM literature (see for discussion and recommendations: Lee et al. 2015)

${ }^{[12]}$ See note [3] or supplementary material for the protocol.

${ }^{[13]}$ Neighborhood is simulated as TRA noticing whether in a radius of 10 ha in any direction there is another forest owner active.

Responses to this article can be read online at: https://www.ecologyandsociety.org/issues/responses. php/12325

\section{Acknowledgments:}

We would like to thank the research group at the University of Osnabrück for providing very valuable feedback on earlier versions of the model and the manuscript. We would like to also thank the anonymous reviewers who allowed this study to strengthen in multiple ways, but also, for their constructive and helpful style.

\section{Data Availability:}

The datalcode that support the findings of this study are openly available in modeling commons at: https://www.comses.net/ codebases/1b1ac7b5-8015-4003-a838-2180586b8083/releases/1.1.01

\section{LITERATURE CITED}

Abildtrup, J., F. Jensen, and A. Dubgaard. 2012. Does the Coase theorem hold in real markets? An application to the negotiations between waterworks and farmers in Denmark. Journal of Environmental Management 93(1):169-176. https://doi.org/10.1016/ j.jenvman.2011.09.004

An, L. 2012. Modeling human decisions in coupled human and natural systems: review of agent-based models. Ecological Modelling 229:25-36. https://doi.org/10.1016/j.ecolmodel.2011.07.010

An, L., M. Linderman, J. Qi, A. Shortridge, and J. Liu. 2005. Exploring complexity in a human-environment system: an agentbased spatial model for multidisciplinary and multiscale integration. Annals of the Association of American Geographers 95(1):54-79. https://doi.org/10.1111/j.1467-8306.2005.00450.x

Armitage, D. R., R. Plummer, F. Berkes, R. I. Arthur, A. T. Charles, I. J. Davidson-Hunt, A. P. Diduck, N. C. Doubleday, D. S. Johnson, M. Marschke, P. McConney, E. W. Pinkerton, and E. K. Wollenberg. 2009. Adaptive co-management for socialecological complexity. Frontiers in Ecology and the Environment 7(2):95-102. https://doi.org/10.1890/070089

Arriagada, R., and C. Perrings. 2013. Making payments for ecosystem services work. Pages 16-57 in P. Kumar and I. Thiaw, editors. Values, payments and institutions for ecosystem management: a developing country perspective. Edward Elgar, Cheltenham, UK. https://doi.org/10.4337/9781781953693.00008

Badia, A., M. Pallares-Barbera, N. Valldeperas, and M. Gisbert. 2019. Wildfires in the wildland-urban interface in Catalonia: vulnerability analysis based on land use and land cover change. Science of the Total Environment 673:184-196. https://doi. org/10.1016/j.scitotenv.2019.04.012

Báliková, K., T. Červená, I. De Meo, R. De Vreese, T. Deniz, A. El Mokaddem, B. Kayacan, F. Larabi, Z. Lìbiete, M. Lyubenova, 
Š. Pezdevšek Malovrh, K. Potočki, O. Pelyukh, B. Rugani, Z. Sarvasova, J. Śálka, M. Stevanov, S. Stojnic, V. Jarský, D. Vuletić, L. Zahvoyska, and A. Paletto. 2020. How do stakeholders working on the forest-water nexus perceive payments for ecosystem services? Forests 11(1):12. https://doi.org/10.3390/ $\underline{\mathrm{f} 11010012}$

Boon, T. E., H. Meilby, and B. J. Thorsen. 2004. An empirically based typology of private forest owners in Denmark: improving communication between authorities and owners. Scandinavian Journal of Forest Research 19(sup004):45-55. https://doi. org/10.1080/14004080410034056

Bösch, M., P. Elsasser, K. Franz, M. Lorenz, C. Moning, R. Olschewski, A. Rödl, H. Schneider, B. Schröppel, and P. Weller. 2018. Forest ecosystem services in rural areas of Germany: insights from the national TEEB study. Ecosystem Services 31:77-83. https://doi.org/10.1016/j.ecoser.2018.03.014

Brukas, V., and O. Sallnäs. 2012. Forest management plan as a policy instrument: stick, carrot or sermon? Land Use Policy 29 (3):605-613. https://doi.org/10.1016/j.landusepol.2011.10.003

Capodaglio, A. G., and A. Callegari. 2018. Can payment for ecosystem services schemes be an alternative solution to achieve sustainable environmental development? A critical comparison of implementation between Europe and China. Resources 7(3):40. https://doi.org/10.3390/resources 7030040

Cervera, T., J. Pino, J. Marull, R. Padró, and E. Tello. 2019. Understanding the long-term dynamics of forest transition: from deforestation to afforestation in a Mediterranean landscape (Catalonia, 1868-2005). Land Use Policy 80:318-331. https://doi. org/10.1016/j.landusepol.2016.10.006

Chen, W. Y., J. Aertsens, I. Liekens, S. Broekx, and L. De Nocker. 2014. Impact of perceived importance of ecosystem services and stated financial constraints on willingness to pay for riparian meadow restoration in Flanders (Belgium). Environmental Management 54(2):346-359. https://doi.org/10.1007/s00267-014-0293$\underline{\mathrm{Z}}$

Consorci Segre Rialb. 2018. Pla urbanístic de l'embassament de Rialb. Document inicial estratègic. Avanç del Pla Director Urbanístic (PDU) de l'embassament de Rialb, Spain.

Cranford, M. 2014. Positive incentives for ecosystem services. Dissertation. The London School of Economics and Political Science, London, UK.

De Cáceres, M., J. Martínez-Vilalta, L. Coll, P. Llorens, P. Casals, R. Poyatos, J. G. Pausas, and L. Brotons. 2015. Coupling a water balance model with forest inventory data to predict drought stress: the role of forest structural changes vs. climate changes. Agricultural and Forest Meteorology 213:77-90. https://doi. org/10.1016/j.agrformet.2015.06.012

De Cáceres, M., M. Mencuccini, N. Martin-StPaul, J. M. Limousin, L. Coll, R. Poyatos, A. Cabon, V. Granda, A. Forner, F. Valladares, and J. Martínez-Vilalta. 2021. Unravelling the effect of species mixing on water use and drought stress in Mediterranean forests: a modelling approach. Agricultural and Forest Meteorology 296:108233. https://doi.org/10.1016/j. agrformet.2020.108233
Dedeurwaerdere, T., A. Polard, and P. Melindi-Ghidi. 2015. The role of network bridging organisations in compensation payments for agri-environmental services under the EU Common Agricultural Policy. Ecological Economics 119:24-38. https://doi. org/10.1016/i.ecolecon.2015.07.025

Deuffic, P., M. Sotirov, and B. Arts. 2018. "Your policy, my rationale". How individual and structural drivers influence European forest owners' decisions. Land Use Policy 79:1024-1038. https://doi.org/10.1016/j.landusepol.2016.09.021

Domínguez, G., and M. Shannon. 2011. A wish, a fear and a complaint: understanding the (dis)engagement of forest owners in forest management. European Journal of Forest Research 130:435-450. https://doi.org/10.1007/s10342-009-0332-0

Engel, S. 2016. The devil in the detail: a practical guide on designing payments for environmental services. International Review of Environmental and Resource Economics 9(1-2):131-177. https://doi.org/10.1561/101.00000076

Engel, S., S. Pagiola, and S. Wunder. 2008. Designing payments for environmental services in theory and practice: an overview of the issues. Ecological Economics 65(4):663-674. https://doi. org/10.1016/j.ecolecon.2008.03.011

European Commission (EC). 2012. Enhancing the effectiveness of payments for ecosystem services (PES). Science for Environment Policy: European Commission DG ENV (30):1-12.

Feranec, J., G. Jaffrain, T. Soukup, and G. Hazeu. 2010. Determining changes and flows in European landscapes 1990-2000 using CORINE land cover data. Applied Geography 30(1):19-35. https://doi.org/10.1016/j.apgeog.2009.07.003

Ferranti, F., P. Vericat, and J. de Koning. 2017. Discourses on sustainable forest management and effects of Natura 2000: a case study of Catalonia, NE Spain. Journal of Environmental Planning and Management 60(12):2085-2102. https://doi.org/10.1080/09640568.2016.1274254

Ferraro, P. J. 2008. Asymmetric information and contract design for payments for environmental services. Ecological Economics 65 (4):810-821. https://doi.org/10.1016/j.ecolecon.2007.07.029

Fletas, M., M. Bayona, and T. Cervera. 2012. Estructura de la propietat forestal de Catalunya. Anàlisi de dades cadastrals. Generalitat de Catalunya Departament d'Agricultura, Ramaderia, Pesca, Alimentació i Medi Natural. Centre de la Propietat Forestal, Barcelona, Spain.

Fletcher, R., and B. Büscher. 2017. The PES conceit: revisiting the relationship between payments for environmental services and neoliberal conservation. Ecological Economics 132:224-231. https://doi.org/10.1016/j.ecolecon.2016.11.002

Folke, C. 2006. Resilience: the emergence of a perspective for social-ecological systems analyses. Global Environmental Change 16(3):253-267. https://doi.org/10.1016/j.gloenvcha.2006.04.002

Fox, A. 2019. Adding 1 billion hectares of forest could help check global warming. Science, 4 July. https://doi.org/10.1126/science. aay 6188

FTiP (Fundació Territori i Paisatge). 2003. Pla de gestió de la conca del riu Rilb a la Baronia de Rialb (La Noguera). FTiP, Spain. 
García-Ruiz, J. M., and N. Lana-Renault. 2011. Hydrological and erosive consequences of farmland abandonment in Europe, with special reference to the Mediterranean region - a review. Agriculture, Ecosystems and Environment 140(3-4):317-338. https://doi.org/10.1016/j.agee.2011.01.003

Getzner, M., J. Meyerhoff, and F. Schläpfer. 2018. Willingness to pay for nature conservation policies in state-owned forests: an Austrian case study. Forests 9(9):537. https://doi.org/10.3390/ $\underline{\mathrm{f} 9090537}$

Górriz-Mifsud, E., E. Varela, M. Piqué, and I. Prokofieva. 2016. Demand and supply of ecosystem services in a Mediterranean forest: computing payment boundaries. Ecosystem Services 17:53-63. https://doi.org/10.1016/j.ecoser.2015.11.006

Grimm, V., U. Berger, D. L. DeAngelis, J. G. Polhill, J. Giske, and S. F. Railsback. 2010. The ODD protocol: a review and first update. Ecological Modelling 221(23):2760-2768. https://doi. org/10.1016/j.ecolmodel.2010.08.019

Guyot, P., and S. Honiden. 2006. Agent-based participatory simulations: merging multi-agent systems and role-playing games. Journal of Artificial Societies and Social Simulation 9(4).

Hogl, K., M. Pregernig, and G. Weiss. 2005. What is new about new forest owners? A typology of private forest ownership in Austria. Small-scale Forest Economics, Management and Policy 4:325-342. https://doi.org/10.1007/s11842-005-0020-y

Horne, P. 2006. Forest owners' acceptance of incentive based policy instruments in forest biodiversity conservation - a choice experiment based approach. Silva Fennica 40(1):359. https://doi. org/10.14214/sf.359

Hujala, T., J. Pykäläinen, and J. Tikkanen. 2007. Decision making among Finnish non-industrial private forest owners: the role of professional opinion and desire to learn. Scandinavian Journal of Forest Research 22(5):454-463. https://doi.org/10.1080/02827580701395434

Institució Catalana d'Estudis Agraris (Icea). 2019. Reflexions sobre les politiques forestals del bosc privat a Catalunya. Icea, Barcelona, Spain.

Institut d'Estadística de Catalunya (Idescat). 2018. El municipi en xifres, Noguera: Baronia de Rialb. Idescat, Catalonia, Spain. [online] URL: https://www.idescat.cat/emex/?id=250426

Jack, B. K., C. Kousky, and K. R. E. Sims. 2008. Designing payments for ecosystem services: lessons from previous experience with incentive-based mechanisms. Proceedings of the National Academy of Sciences of the United States of America 105(28):9465-9470. https://doi.org/10.1073/pnas.0705503104

Janssen, M. A. 2001. An exploratory integrated model to assess management of lake eutrophication. Ecological Modelling 140 (1-2):111-124. https://doi.org/10.1016/S0304-3800(01)00260-5

Janssen, M. A., B. H. Walker, J. Langridge, and N. Abel. 2000. An adaptive agent model for analysing co-evolution of management and policies in a complex rangeland system. Ecological Modelling 131(2-3):249-268. https://doi.org/10.1016/ $\underline{\mathrm{S} 0304-3800(00) 00256-8}$

Kilgore, M. A., J. L. Greene, M. G. Jacobson, T. J. Straka, and S. E. Daniels. 2007. The influence of financial incentive programs in promoting sustainable forestry on the nation's family forests. Journal of Forestry 184-191.

Kline, J. D., R. J. Alig, and R. L. Johnson. 2000. Forest owner incentives to protect riparian habitat. Ecological Economics 33 (1):29-43. https://doi.org/10.1016/S0921-8009(99)00116-0

Kuemmerle, T., P. Olofsson, O. Chaskovskyy, M. Baumann, K. Ostapowicz, C. E. Woodcock, R. A. Houghton, P. Hostert, W. S. Keeton, and V. C. Radeloff. 2011. Post-Soviet farmland abandonment, forest recovery, and carbon sequestration in western Ukraine. Global Change Biology 17(3):1335-1349. https:// doi.org/10.1111/j.1365-2486.2010.02333.X

Kuipers, B. T., S. G. C., and K. Potter-Witter. 2013. Identifying appropriate communication means for reaching nonindustrial private forest landowners. Journal of Forestry 111(1):34-41. https://doi.org/10.5849/jof.12-006

Lasanta, T., J. Arnáez, N. Pascual, P. Ruiz-Flaño, M. P. Errea, and N. Lana-Renault. 2017. Space-time process and drivers of land abandonment in Europe. CATENA 149:810-823. https://doi. org/10.1016/j.catena.2016.02.024

Layton, D. F., and J. Siikamäki. 2009. Payments for ecosystem services programs: predicting landowner enrollment and opportunity cost using a beta-binomial model. Environmental and Resource Economics 44:415. https://doi.org/10.1007/s10640-009-9293-5

Lee, J. S., T. Filatova, A. Ligmann-Zielinska, B. HassaniMahmooei, F. Stonedahl, I. Lorscheid, A. Voinov, G. Polhill, Z. Sun, and D. C. Parker. 2015. The complexities of agent-based modeling output analysis. Journal of Artificial Societies and Social Simulation 18(4):4. https://doi.org/10.18564/jasss. 2897

Lundberg, L., U. M. Persson, F. Alpizar, and K. Lindgren. 2018. Context matters: exploring the cost-effectiveness of fixed payments and procurement auctions for PES. Ecological Economics 146:347-358. https://doi.org/10.1016/j.ecolecon.2017.11.021

MacDonald, D., J. R. Crabtree, G. Wiesinger, T. Dax, N. Stamou, P. Fleury, J. Gutierrez Lazpita, and A. Gibon. 2000. Agricultural abandonment in mountain areas of Europe: environmental consequences and policy response. Journal of Environmental Management 59(1):47-69. https://doi.org/10.1006/jema.1999.0335

Makkonen, M., S. Huttunen, E. Primmer, A. Repo, and M. Hildén. 2015. Policy coherence in climate change mitigation: an ecosystem service approach to forests as carbon sinks and bioenergy sources. Forest Policy and Economics 50:153-162. https://doi.org/10.1016/j.forpol.2014.09.003

Mansourian, S., D. Vallauri, and N. Dudley, editors. 2005. Forest restoration in landscapes: beyond planting trees. Springer Science+ Business, New York, New York, USA. https://doi. org/10.1007/0-387-29112-1

Mäntymaa, E., V. Ovaskainen, A. Juutinen, and L. Tyrväinen. 2018. Integrating nature-based tourism and forestry in private lands under heterogeneous visitor preferences for forest attributes. Journal of Environmental Planning and Management 61 (4):724-746. https://doi.org/10.1080/09640568.2017.1333408

Medema, W., B. S. Jeffrey, and P. J. McIntosh. 2008. From premise to practice: a critical assessment of integrated water resources 
management and adaptive management approaches in the water sector. Ecology and Society 13(2):29. https://doi.org/10.5751/ ES-02611-130229

Mekonnen, M. M., and A. Y. Hoekstra. 2016. Four billion people facing severe water scarcity. Science Advances 2(2):e1500323. https://doi.org/10.1126/sciadv.1500323

Meyer, C., M. Reutter, B. Matzdorf, C. Sattler, and S. Schomers. 2015. Design rules for successful governmental payments for ecosystem services: taking agri-environmental measures in Germany as an example. Journal of Environmental Management 157:146-159. https://doi.org/10.1016/j.jenvman.2015.03.053

Millar, C. I., N. L. Stephenson, and S. L. Stephens. 2007. Climate change and forests of the future: managing in the face of uncertainty. Ecological Applications 17(8):2145-2151. https://doi. org/10.1890/06-1715.1

Moreira, F., and D. Russo. 2007. Modelling the impact of agricultural abandonment and wildfires on vertebrate diversity in Mediterranean Europe. Landscape Ecology 22:1461-1476. https:// doi.org/10.1007/s10980-007-9125-3

Muradian, R., E. Corbera, U. Pascual, N. Kosoy, and P. H. May. 2010. Reconciling theory and practice: an alternative conceptual framework for understanding payments for environmental services. Ecological Economics 69(6):1202-1208. https://doi. org/10.1016/j.ecolecon.2009.11.006

Navarro, L. M., and H. M. Pereira. 2015. Rewilding abandoned landscapes in Europe. Pages 3-23 in H. M. Pereira and L. M. Navarro, editors. Rewilding European landscapes. Springer, Cham, Switzerland. https://doi.org/10.1007/978-3-319-12039-3 1

Ní Dhubháin, Á., R. Cobanova, H. Karppinen, D. Mizaraite, E. Ritter, B. Slee, and S. Wall. 2007. The values and objectives of private forest owners and their influence on forestry behaviour: the implications for entrepreneurship. Small-Scale Forestry 6:347-357. https://doi.org/10.1007/s11842-007-9030-2

Nordlund, A., and K. Westin. 2011. Forest values and forest management attitudes among private forest owners in Sweden. Forests 2(1):30-50. https://doi.org/10.3390/f2010030

Oliva, J., C. Castaño, E. Baulenas, G. Domínguez, J. R. GonzálezOlabarria, and D. Oliach. 2016. The impact of the socioeconomic environment on the implementation of control measures against an invasive forest pathogen. Forest Ecology and Management 380:118-127. https://doi.org/10.1016/j.foreco.2016.08.034

Olsson, P., L. H. Gunderson, S. R. Carpenter, P. Ryan, L. Lebel, C. Folke, and C. S. Holling. 2006. Shooting the rapids: navigating transition to adaptive governance of social-ecological systems. Ecology and Society 11(1):18. https://doi.org/10.5751/ES-01595-110118

Organisation for Economic Co-operation and Development (OECD). 2010. Paying for biodiversity: enhancing the costeffectiveness of payments for ecosystem services. OECD, Paris, France. https://doi.org/10.1787/9789264090279-en

Pahl-Wostl, C. 2002. Participative and stakeholder-based policy design, evaluation and modeling processes. Integrated Assessment 3(1):3-14. https://doi.org/10.1076/iaij.3.1.3.7409
Pahl-Wostl, C. 2007. The implications of complexity for integrated resources management. Environmental Modelling and Software 22(5):561-569. https://doi.org/10.1016/j.envsoft.2005.12.024

Pahl-Wostl, C. 2015. Water governance in the face of global change: from understanding to transformation. Springer, Cham, Switzerland.

Piqué, M., P. Vericat, and M. Beltrán. 2017. Orgest: Regional guidelines and silvicultural models for sustainable forest management. Forest Systems 26(2):1-6. https://doi.org/10.5424/ fs/2017262-10627

Primmer, E., R. Paloniemi, J. Similä, and A. Tainio. 2014. Forest owner perceptions of institutions and voluntary contracting for biodiversity conservation: not crowding out but staying out. Ecological Economics 103:1-10. https://doi.org/10.1016/j. ecolecon.2014.04.008

Pujol, J., J. Berbel, F. Ramírez de Cartagena, D. Viaggi, and M. Raggi. 2006. Evaluation of markets for irrigation water in the internal river basins of Catalonia, Spain. Spanish Journal of Agricultural Research 4(1):3. https://doi.org/10.5424/sjar/2006041-173

Railsback, S., D. Ayllón, U. Berger, V. Grimm, S. Lytinen, C. Sheppard, and J. Thiele. 2017. Improving execution speed of models implemented in NetLogo. Journal of Artificial Societies and Social Simulation 20(1):3. https://doi.org/10.18564/jasss. 3282

Railsback, S. F., and V. Grimm. 2020. Agent-based and individualbased modeling: a practical introduction. Second edition. Princeton University Press, Princeton, New Jersey, USA.

Reed, M. S., K. Allen, A. Attlee, A. J. Dougill, K. L. Evans, J. O. Kenter, J. Hoy, D. McNab, S. M. Stead, C. Twyman, A. S. Scott, M. A. Smyth, L. C. Stringer, and M. J. Whittingham. 2017. A place-based approach to payments for ecosystem services. Global Environmental Change 43:92-106. https://doi.org/10.1016/j. gloenvcha.2016.12.009

Sattler, C., and B. Matzdorf. 2013. PES in a nutshell: from definitions and origins to PES in practice-approaches, design process and innovative aspects. Ecosystem Services 6:2-11. https:// doi.org/10.1016/j.ecoser.2013.09.009

Sattler, C., S. Trampnau, S. Schomers, C. Meyer, and B. Matzdorf. 2013. Multi-classification of payments for ecosystem services: How do classification characteristics relate to overall PES success? Ecosystem Services 6:31-45. https://doi.org/10.1016/j.ecoser.2013.09.007

Schleyer, C., and T. Plieninger. 2011. Obstacles and options for the design and implementation of payment schemes for ecosystem services provided through farm trees in Saxony, Germany. Environmental Conservation 38(4):454-463. https://doi.org/10.1017/ S0376892911000361

Schomers, S., and B. Matzdorf. 2013. Payments for ecosystem services: a review and comparison of developing and industrialized countries. Ecosystem Services 6:16-30. https://doi. org/10.1016/j.ecoser.2013.01.002

Schomers, S., B. Matzdorf, C. Meyer, and C. Sattler. 2015. How local intermediaries improve the effectiveness of public payment for ecosystem services programs: the role of networks and agri- 
environmental assistance. Sustainability 7(10):13856-13886. https://doi.org/10.3390/su71013856

Schouten, M., P. Opdam, N. Polman, and E. Westerhof. 2013. Resilience-based governance in rural landscapes: experiments with agri-environment schemes using a spatially explicit agentbased model. Land Use Policy 30(1):934-943. https://doi. org/10.1016/j.landusepol.2012.06.008

Serbruyns, I., and S. Luyssaert. 2006. Acceptance of sticks, carrots and sermons as policy instruments for directing private forest management. Forest Policy and Economics 9(3):285-296. https://doi.org/10.1016/j.forpol.2005.06.012

Serra, P., A. Vera, A. F. Tulla, and L. Salvati. 2014. Beyond urbanrural dichotomy: exploring socioeconomic and land-use processes of change in Spain (1991-2011). Applied Geography 55:71-81. https://doi.org/10.1016/j.apgeog.2014.09.005

Sheremet, O., E. Ruokamo, A. Juutinen, R. Svento, and N. Hanley. 2018. Incentivising participation and spatial coordination in payment for ecosystem service schemes: forest disease control programs in Finland. Ecological Economics 152:260-272. https://doi.org/10.1016/j.ecolecon.2018.06.004

Sotirov, M., O. Sallnäs, and L. O. Eriksson. 2019. Forest owner behavioral models, policy changes, and forest management. An agent-based framework for studying the provision of forest ecosystem goods and services at the landscape level. Forest Policy and Economics 103:79-89. https://doi.org/10.1016/j.forpol.2017.10.015

Symeonakis, E., A. Calvo-Cases, and E. Arnau-Rosalen. 2007. Land use change and land degradation in southeastern Mediterranean Spain. Environmental Management 40:80-94. https://doi.org/10.1007/s00267-004-0059-0

Toderi, M., M. Francioni, G. Seddaiu, P. P. Roggero, L. Trozzo, and P. D'Ottavio. 2017. Bottom-up design process of agrienvironmental measures at a landscape scale: evidence from case studies on biodiversity conservation and water protection. Land Use Policy 68:295-305. https://doi.org/10.1016/j.landusepol.2017.08.002

Vadell, E., S. De-Miguel, and J. Pemán. 2016. Large-scale reforestation and afforestation policy in Spain: a historical review of its underlying ecological, socioeconomic and political dynamics. Land Use Policy 55:37-48. https://doi.org/10.1016/j. landusepol.2016.03.017

Vedel, S. E., J. B. Jacobsen, and B. J. Thorsen. 2015. Forest owners' willingness to accept contracts for ecosystem service provision is sensitive to additionality. Ecological Economics 113:15-24. https:// doi.org/10.1016/j.ecolecon.2015.02.014

Wells, G., C. Ryan, J. Fisher, and E. Corbera. 2020. In defence of simplified PES designs. Nature Sustainability 3:426-427. https:// doi.org/10.1038/s41893-020-0544-3

Wilensky, U. 1999. NetLogo. Center for Connected Learning and Computer-Based Modelling, Northwestern University, Evanston, Illinois, USA. [online] URL: http://ccl.northwestern.edu/netlogo/

Wilensky, U., and W. Rand. 2015. An introduction to agent-based modeling: modeling natural, social, and engineered complex systems with NetLogo. MIT Press, Cambridge, Massachusetts, USA.
Wunder, S. 2005. Payment for ecosystem services: some nuts and bolts. CIFOR Occasional Paper No. 42.

Wunder, S. 2015. Revisiting the concept of payments for environmental services. Ecological Economics 117:234-243. https://doi.org/10.1016/j.ecolecon.2014.08.016

Wunder, S., R. Brouwer, S. Engel, D. Ezzine-De-Blas, R. Muradian, U. Pascual, and R. Pinto. 2018. From principles to practice in paying for nature's services. Nature Sustainability 1:145-150. https://doi.org/10.1038/s41893-018-0036-X

Wunder, S., R. Brouwer, S. Engel, D. Ezzine-de-Blas, R. Muradian, U. Pascual, and R. Pinto. 2020. Reply to: in defence of simplified PES designs. Nature Sustainability 3:428-429. https://doi.org/10.1038/s41893-020-0545-2 


\section{ODD Protocol for the SESPES model}

The model description follows the ODD (Overview, Design concepts, Details) protocol for describing individual- and agent-based models in its updated version (Grimm et al., 2010).

\section{Purpose}

Background. Incentives policies for environmental conservation purposes under the label of payment for ecosystem services (PES) gained international attention with the publication of the Millennium Ecosystem Assessment (MEA) in the 2000s and show a solid expansion in recent years with China and America Latina taking the lead (Salzman, Bennett, Carroll, Goldstein, \& Jenkins, 2018). With its spread, a fierce debate in the academic literature started about the optimal design of such policies (Wells, Ryan, Fisher, \& Corbera, 2020; Wunder et al., 2020, 2018). So far, several studies have compared schemes and provided an array of design principles for PES schemes. However, the majority of these studies compare examples from mainly developing countries with few recent exceptions (see e.g. Capodaglio \& Callegari, 2018). One of the conflicts with such comparisons is the high interaction that context play in the effectiveness of PES policies -including the environmental, socio-economic and politic contexts (Jack, Kousky, $\&$ Sims, 2008). Thus, the design principles applicable to developing countries for mere geo-political reasons may not be applicable to other areas such as in Europe.

Purpose. The purpose of the proposed agent-based model is to intervene in the debate about PES policy design, implementation and context. We use the case for a woodland-for-water payment for ecosystem services (PES) and model its implementation in a local area of Catalonia (NE Spain). Our question of interest is: how do structural and agent-based factors affect the effectiveness of an incentive policy to integrate the forest and water sector? By structural factors, we mean different designs of a PES policy. For agent-based factors, we make use of the literature on landowner behavioral studies about reception and reaction to incentive policies from European-focused studies. By success, we understand that both the ecological but also social goals of the policy are reached in the most effective manner. Our focus in Europe surges from the general context of land abandonment that many Mediterranean areas and Eastern countries are experiencing, and the growing interest from policy-makers and practitioners on the implementation of PES schemes to ameliorate this situation.

\section{Entities, state variables, and scales}

Agents/individuals. The agents of the model are forest owners with two characteristics: (a) belonging to a collective with behavioral characteristics (see Collectives below) and (b) owning a random number of ha of forests with conifers and broadleaf (see Environment). The number of owners can be modified by the modeler with an input box. We run the model with 1000 owners, which end up owning ca $50 \%$ of the total area and $>80 \%$ of the forested area -which is close to the amount of $\mathrm{km}^{2}$ of private ownership for our case study. Whereas the exact number changes every time due to stochastic processes, the average of 100 runs tends to the known amount of private ownership. In the region, Catalonia, there is property atomization by which $95.2 \%$ of owners have less than 25 ha (ICEA, 2019). In the county of the area we modelled, la Noguera, there is an estimate of ca. 1800 owners with a third each of $>25$ ha, 125 ha and $<1$ ha (Fletas, Bayona, \& Cervera, 2012). The model represents this situation, with owners receiving from 1 to 25 ha in random numbers. Forest owners are also allocated a typology based on behavioral studies. This is further explained in the ODD section: sub-models.

Spatial units (e.g., grid cells). The spatial units are type of land, and includes four types of entities: conifers, broadleaf, shrubland (i.e. vegetation cover) and water or agricultural land. Whereas this later fields have no state variable but just represents the geographical area used for the spatially explicit model, the other three change under certain influences. The patches have always the same identity in the initiation but they might go under land conversion or land management processes. With land conversion: 
conifers and broadleaf receive a random age and at a certain 'old' age they either turn into shrubland or reproduce leaving a younger tree of the same species. This process is random, with greater chances of conversion than regeneration due to the general context of climate change and drought (Cáceres et al., 2015). They can also be 'managed' by forest owners, by which they are cut and naturally regenerated. Both conifers and broadleaf have a certain water efficiency rate: this can be impoverished due to climate change or improved through regeneration/management. The rate they receive is random following the estimations for this type of trees in the region.

Environment. The environment of the model is characterized by scenarios with and without climate change. Without climate change, there is a certain amount of stable precipitation and rare drought episodes. This is based on climatological data for the area of study. With climate change, the amount of precipitation decreases and droughts occur more often. Droughts produce a certain amount of tree dieback. The climate change projections are based on a climate model for the region (Catalonia), and affect not only precipitation and droughts, but also the rate of water use efficiency of trees.

Collectives. This is the most important theoretical assumption in our model, which we could not contrast with actual data for the region, but we base its distribution in expertise knowledge [from the agency responsible for forest private property in the region plus several EU-funded studies conducted there]. Forest owners are allocated in a certain 'collective'. These collectives imply a set of social norms and cultural values and determine the decision model that agents follow. We build the agent's decision model based on theories of forest owner typologies and expected behavioral attributes. We implement four out of the six typologies present in the literature and based on empirical data from European forest owner studies (Sotirov, Sallnäs, \& Eriksson, 2017), emulating the situation in our case study. These are (1) environmentalist (do not manage / manage long-term); (2) multi-functionalists (manage short-term / manage long-term); (3) traditionalists (manage short-term / manage long-term) and (4) passives (do not manage). Excluded typologies are (5) optimizers and (6) maximizers -who are generally large-scale forest owners not present in our case study (Fletas et al., 2012).

The management decisions of collectives are based on the characteristics of the policy. The characteristics can be changed in the model interface, and were based on a review of the PES literature. These include: payment frequency, presence of an intermediary, number of ecosystem services and cost coverage. They are all binary. Management starts at model initiation, and it repeats itself depending on the type of policy design in place (short / long term / attrition / none). There is one exception to this rule: traditionalists do not respond to changes in policy design, but follow their direct neighbors.

Spatial and temporal scales. The model landscape consists of an area of $270 \mathrm{~km}^{2}$. There are 32508.0 pixels and each represents $0.8 \mathrm{ha}$. One time step represents one year and simulations run for 100 years -in netlogo, until the environment loses its resilience, with forested areas converted into shrubland. The model landscape data is incorporated via the GIS extension. The required document ("mscr_raster.asc") is provided as additional documentation in COMSES or in the Netlogo databases.

\section{Process overview and scheduling}

The first step of the model is loading the map to display the model landscape based on GIS data. This distributes the land cover types representing the territory. At this stage, the observer keeps track of the land cover composition -and will do so until the end of the model. Land cover receives a color based on the tree species, which are grouped in two main categories: conifers and broadleaf. Age is distributed randomly among the later between 20 and 150 or 100 accordingly. Precipitation (global) and water efficiency (individual) is set at the basis. The model simulation currently includes direct distribution of forest owners across the territory when setting up the landscape, but the code can be easily modified to separate the two steps. In this agent distribution, forest owners receive a number of ha distributed jointly across the territory, as well as a forest owner category (collective). At this stage, the modeler needs to decide also on the characteristics of the policy design. 
There are three main processes which influence the forest cover once the model is initiated: the decisions of forest owners on managing or not and the type of management ('initiate-management'), the effects of climate change (if activated) on the environmental variables ('change-blue-water', 'experience-drought'), and their own aging ('grow-old'). Management is a discrete variable which manifests at the same time for each forest owner category: it can be short or long term -information which is based on the management recommendations from the forest authority of the region (Piqué, Vericat, \& Beltrán, 2017). This happens differently depending on policy design and forest owner, as well as forest type. Drought happens increasingly often the lower the levels of precipitation (lowered by climate change across the years) and produces tree conversion to scrubland in older trees in a random fashion. As forests stands are regenerated, their state variables vary to show base levels that will be again modified through either climate change effects or aging. This means that there is an asynchronous updating of these variables in land cover with forest. One factor our model does not include is seasonality, provided we model the changes in a yearly basis and thus we include only known average data processes.

Note: the code in Netlogo is accompanied by the pseudo-code which was used to build the model.

\section{Design concepts}

Basic principles. We understand our study as a case of policy integration across the forest and water sectors, and some of the policy integration literature understands it as a complex system (Briassoulis \& McDonald, 2005). This implies that every manifestation of policy integration across natural resources will contain the known properties of complex systems. The second argument requiring the model surges from the literature on forest owner behavior in Europe. Generally, scholars have observed policy attrition by which land owners abandon a policy once implemented or do not change their management and reject the policy despite the presence of financial incentives. For this reason, the effects of a policy should incorporate the element of disengagement of the community, moreover in the place of payment for ecosystem services that consist of a voluntary process. Thus, the aim of the study is to observe if policy designs would imply important differences among them -and observe the interplay between these structural factors and agent-based factors such as social norms and values. The hypotheses are, following the literature, that some forest owners will feel aligned with the conservation goals of the policy and act accordingly, but some forest owners will maintain a passive behavior independently of any factor. In a continuum between these two extremes, there will be owners who feel peer-pressure and follow a certain leadership, whilst others might show only partial compliance. Finally, at ecological level, we introduce the estimates of the impact of climate change on forest water use efficiency (WUE) as modelled for the region with the model GOTILWA+ (see input data).

Emergence. The main output of interest is the amount of managed forest. This factor varies depending on the distribution of forest owners typologies. From the typologies, the one with most room for emergency is the typology of traditionalists, who manage following the decision that their neighbors take. In case being surrounded by passive neighbors, low participation in the policy scheme is expected and with it, the water use efficiency gains from the implementation of the PES policy.

Adaptation. The forest owners when they opt for managing their territory they will do so by choosing the most damaged forest stands. The implementation of this adaptive behavior is made through the age as proxy for the condition of a forest. The aim is to optimize the average water efficiency rate, provided the goal of the PES scheme is to change the management to improve water-related ecosystem services among which those of provision.

Objectives. The objectives of the agents are masked by their belonging to a certain typology. These typologies are based on empirical data from studies comparing several European datasets and cluster landowners based on the degree to which they respond to a model of homo economicus, sociologicus 
or psychologicus (Deuffic, Sotirov, \& Arts, 2018; Sotirov et al., 2017). Each have different affinity to more material-based incentive such as fiduciary to more environmentally driven behaviors (including different management preferences). Thus, this factor is only included indirectly in the model.

Learning. Learning is not specifically modelled in the current version of the model. The only collective that could display signs of learning, nonetheless, is the traditionalists: the more they observe neighbors participating in the PES scheme, the more they would change their own management decisions by changing from passive to active behaviors.

Prediction. The current version of the model does not include prediction. This is one of the weaknesses of behavioral models of forest owners because they are based on the assumption that values are static. Because our model includes the effects of climate change, as well as a long period of time, it is possible that with greater impacts on the region forest owners would change their values and thus adapt decisions on the best management type to meet their values. At the same time, at the ecological level, the risk of forest fires and rendering parts of the landscape degraded due to droughts would also change the possibilities available to landowners and forest authorities (the implied PES financers).

Sensing. One of the forest owner typologies (traditionalists) notices how their neighbors perform: the other typologies are driven by internal cues. In terms of agent-environment, forest owners sense those trees stands that are more damaged (older) and they start managing them rather than younger ones. Costs for cognition and for gathering information are not explicitly included in the model.

Interaction. At model initiation, the territory is distributed across forest owners and they are allocated a certain number of ha. This allocations will not overlap and remain the same, independently of the state of the forest stands. Implicitly, one of the policy design characteristics assumes interaction between the forest authorities and forest owners, with the presence of an intermediary. However, this aspect is not modelled and does only affect the decision to manage of certain owners.

Stochasticity. There are several sources of stochasticity. In order of appearance in the model: the size of owned territory by each forest owner, the age of trees, the frequency and impact of drought -with increases depending on the level of precipitation-, and finally, the level and change in water use efficiency in trees. By the climate models of the region it is known that this level and its modification will not always be of a fixed rate but it will imply a certain percentage. Every time a forest parcel is managed, the forest stands will take a random number within the expected range.

Observation. The data collected from the ABM model is the number of owned and managed ha by forest owner typology, and the evolution of the average water use efficiency rate. This data is collected by types of policy design. There are four main scenarios modelled: one scenario without the presence of the policy, the optimal policy design in which all best practices are activated, the long-term policy design, by which 'close-to-nature' policies with lower frequency of management is activated and finally, the below-cost-coverage policy -by which only multi-functionalists react to the presence of the policy.

\section{Initialization}

At initialization, the modeler chooses three aspects, related to each of the sub-models.

- For the ecological sub-model, the most important decision is to decide if climate change effects are activated. If activated, the other variables (precipitation and evapotranspiration -ET), will change across the years: the set up points are based on data from the case study.

- For the social sub-model, the user needs to choose the number of forest owners (for the study, established at 1000) and the distribution of forest owner typologies (\% of each typology). Number of ha per owner are then randomly distributed. The number of management plans are also 
distributed at this stage. The current number reflects the actual known presence of forest management plans from private forest owners.

- For the structural sub-model, the modeler chooses the policy design. This will have impacts on the type of management implemented by forest owners depending on their collective belonging. If the first characteristic is activated ('below-cost-coverage?'), this is equal to a scenario without policy and thus just the evolution of the ecosystem without the PES policy in place.

Once these variables are selected and the 'world' is created, the model landscape is always placed identically following GIS data from the area, including distribution of broadleaf and conifers. Trees receive a random age between 20 and 150 years. Forest owners receive also a property between 1 and 30 ha, following the forest ownership distribution of the case study.

The table below displays the base values of these mentioned variables (sources discussed next):

\begin{tabular}{|c|c|c|c|}
\hline & Data & Base values & Source \\
\hline \multirow{13}{*}{ 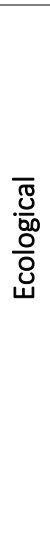 } & Average annual precipitation & $575 \mathrm{~mm} / \mathrm{y}$ & Management Plan of Rialb \\
\hline & Annual change & $-0.2 \% / y$ & \\
\hline & ET by species and change & & \multirow{9}{*}{ GOTILWA+ } \\
\hline & Black pine & $65-85 \%,+5 \% / 150 y$ & \\
\hline & Oak & $85-92 \%,+5 \% / 150 y$ & \\
\hline & Run-off by species and change & & \\
\hline & Black pine & $15-35 \%,-5 \% / 150 y$ & \\
\hline & Oak & $8-15 \%,-5 \% / 150 y$ & \\
\hline & Impact of management & & \\
\hline & On blue water, black pine & $0-10 \%$ & \\
\hline & On blue water, oak & $0-5 \%$ & \\
\hline & Land cover (see Fig.1) & Pinus+ as conifers; Quercus+ as broadleaf & GIS data \\
\hline & Tree age & $\begin{array}{l}\text { Trees receive a (random) age between 20- } \\
\text { 150/100 years depending on specie. }\end{array}$ & - \\
\hline \multirow{5}{*}{$\begin{array}{l}\bar{\pi} \\
\stackrel{0}{0}\end{array}$} & Property type & $93 \%$ private & \multirow{4}{*}{ Management Plan of Rialb } \\
\hline & Number of owners & 1000 & \\
\hline & Number of management plans & $10 \%$ & \\
\hline & Number of $\mathrm{km}^{2}$ & $280 \mathrm{~km}^{2} / 350 \mathrm{~km}^{2}$ & \\
\hline & Typology of forest owner & Behavioural models & (Sotirov et al., 2017) \\
\hline \multirow{4}{*}{ 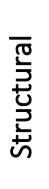 } & Recurrent payments & ST + LT Management with attrition & \multirow{4}{*}{$\begin{array}{l}\text { ORGEST guides } \\
\text { Short-term ST: every 15/35 } \\
\text { Long-term LT: every 50/100 }\end{array}$} \\
\hline & Presence of intermediary & ST management / no management & \\
\hline & N environmental goals & LT management & \\
\hline & Financial coverage & ST + LT Management / No management & \\
\hline
\end{tabular}

Figure 1. Land cover distribution

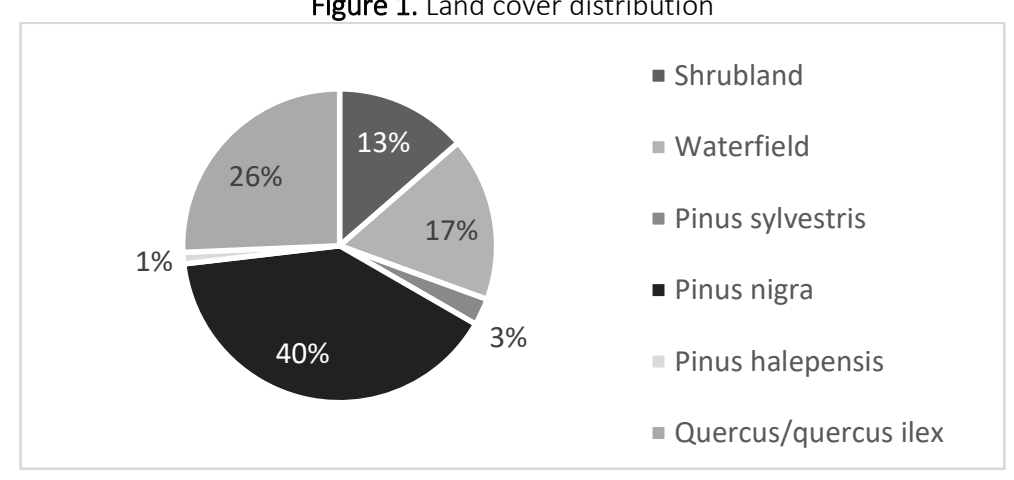


As observed in the table above, there are several data sources mentioned.

- GIS data. The GIS is used to implement a spatially-explicit model. It contains data on the type of forest species present in the area as well as their distribution. Fig. 1 shows the land cover.

- Management plan of Rialb. The MP of the Rialb area was created by the Foundation 'Territori i paisatge', and it describes the main characteristics of our case study (FTiP, 2003). It was used to obtain average precipitation and the climate change projections affecting it.

- GOTILWAt. The model name is an acronym for Growth Of Trees Is Limited by WAter. As the name indicates, this mechanistic deterministic forest growth model combines climate and forest data to simulate forest growth from different management techniques (including management absence) (Gracia, Sabaté, \& Sánchez, 2003). We use it in combination with the ORGEST guides as explained next.

- ORGEST guides. The ORGEST guides are sustainable and multifunctional forest management guides developed for mixed and pure forest stands of Catalonia (Piqué et al., 2017). They were requested from the Forest Ownership Center (Minister of Agriculture) to support private and public forest management decisions, taking into account the expected effects of climate change in a private area. From these guides, we obtain the number of years suggested to manage a certain forest stand (i.e. pinus nigra, quercus ilex) to improve water use efficiency. Specifically, we use the outputs from an EU-funded project, DEMORGEST, which used the ORGEST guides in combination with GOTILWA+ (Nadal-Sala, Sabaté, Gracia, \& CPF, 2014).

- Workshop. Two members of our team are from the Forest Ownership Center (CPF) of Catalonia, acting as partners in an EU-funded project studying innovations for forests ecosystems, among which the implementation of Payment for Ecosystem Services (Hz2020 Sincere). The chosen case is Rialb, where we decided to develop the current agent-base model to support the research process about the effects of a PES scheme at the ecological and social systems in the area. The workshop was held with stakeholders, including forest owners and local authorities, and discussed different designs for the PES scheme that would facilitate participation from the community. For more information, see the manuscript accompanying our model.

\section{Sub-models}

The manuscript accompanying this model presents further information about the interaction between models. Here, we summarize the information and some of the base scenario data of the sub-models.

Ecological sub-model

- Tree aging. Every year trees grow older. Older trees are the ones selected for management and also more susceptible to get affected by drought.

- Climate change. The effects of climate change are two-fold: on the decrease in annual average precipitation and the higher rate of evapotranspiration from the two forest species (conifers and broadleaf). This later is labelled 'green water'.

- Precipitation. Decreases $1.15 \mathrm{~mm}$ per year.

- Blue water (to change-blue-water). Blue water is the percentage left of water after the process of evapotranspiration (ET). It is calculated in percentage, and it decreases 0.03 yearly, which implies a lowered water yield.

- Drought. Observed that drought is affected by climate change but also by forest structure, with land abandonment processes and its consequent increase in forest mass (forest growth and densification) maintaining similar patterns of drought stress (de Caceres et al., 2015). Main problem of difficult prediction of drought effects on tree decay or mortality (idem). 
In the model (to experience-drought), drought is an event experienced by the landscape every 20 years. It affects trees older than 100 years in a rate that changes depending on the levels of precipitation: (a) Over $500 \mathrm{~mm} /$ year. A dice is rolled and depending on the number, at $10 \%$ chance each, trees turn brown (dieback) or become scrubland; (b) 500-450 mm/year. Same processes, at 20\% change; and (c) below $450 \mathrm{~mm} /$ year. Same processes, at $25 \%$ chance.

\section{Social and policy sub-models}

The objective of the policy is to incentivize landowners to change their management. To manage, in the context of our model means thinning the forest every certain shorten periods and cutting followed by natural regeneration. In this later situation, new trees reset age to 20 and reduce the evapotranspiration rate. This later, by a $0-10 \%$ (random) for conifers and a 0-5\% (random) for broadleaf. Management can imply either both (thinning and cutting) or only thinning, depending on the collective of forest owners.

- Management type (DEMORGEST):

- Thinning (short-conifer): every 15 years

- Thinning-broadleaf (short- broadleaf): every 35 years

- End of rotation (long-conifer): every 50 years

- End of rotation (long-broadleaf): every 100 years

The forest owner typologies interact with the type of policy design which is in place. The two tables below show how each of the categories is expected to proceed following its core values.

\begin{tabular}{|c|c|c|}
\hline Forest owner & $\begin{array}{l}\text { Behavioral models } \\
\text { (Sotirov et al., 2017) }\end{array}$ & Implemented in SESPES \\
\hline Optimizers (0) & $\begin{array}{l}\text { Intensive profit-oriented even-aged for- } \\
\text { estry while respecting (minimal) rules }\end{array}$ & Absent \\
\hline Traditionalists $(\mathrm{T})$ & $\begin{array}{l}\text { Low intensive, close-to-nature forestry } \\
\text { based on family tradition, local } \\
\text { knowledge and sporadic needs }\end{array}$ & $\begin{array}{l}\text { Triggered by neighbors' behavior, but not } \\
\text { by policy design. } \\
\text { If neighbors manage, they also initiate } \\
\text { manage with thinning and cutting periods. }\end{array}$ \\
\hline Maximizers (M) & $\begin{array}{l}\text { Highly intensive (short-rotation) profit- } \\
\text { oriented forestry; Sometimes without re- } \\
\text { specting rules (e.g. "illegal loggers") }\end{array}$ & Absent \\
\hline Passives (P) & $\begin{array}{l}\text { Passive/little management due to lack of } \\
\text { interest in forestry according to urban } \\
\text { values and life style }\end{array}$ & Passives never manage \\
\hline $\begin{array}{l}\text { Multi-functional- } \\
\text { ists (MF) }\end{array}$ & $\begin{array}{l}\text { Medium intensive, mixed-objective for- } \\
\text { estry in respect of professional forestry } \\
\text { rules and norms }\end{array}$ & $\begin{array}{l}\text { Very responsive to policy design. Generally } \\
\text { do the complete management (thinning } \\
\text { and cutting) unless more than two ES goals } \\
\text { are pursued (due to trade-offs). }\end{array}$ \\
\hline $\begin{array}{l}\text { Environmentalists } \\
\text { (E) }\end{array}$ & $\begin{array}{l}\text { Passive non-intervention and/or exten- } \\
\text { sive forest management due to environ- } \\
\text { mental core beliefs and values }\end{array}$ & $\begin{array}{l}\text { They are responsive to policy design and if } \\
\text { triggered, they will only manage long-term } \\
\text { due to values. }\end{array}$ \\
\hline
\end{tabular}


Policy design

Below-cost-coverage?

One-time-payment?

\section{No-intermediary?}

Additional-ES-goal?
Explanation

The policy covers (or not) the cost of the change in management required to im-

prove water bodies. If not, the scenario is equal to only the ecosystem submodel.

Payment can be done regularly or at the end of a management period. Regular pay-

ments were shown to maintain landowner participation in the PES scheme. Thus, if

one-time payment is activated, it represents a situation of attrition: every certain

years (15), the number of owners reduces by $10 \%$ each time.

The figure of an intermediary (e.g. the administration, a coordinating agency, etc.)

has been shown to improve PES scheme participation and commitment.

To pursue more than one goal is detrimental provided the different management requirements it can imply.

The below figure maps the type of policy and the response expected from forest owners:

Figure 2. Type of policy design and behavioral responses: opted-for scenarios

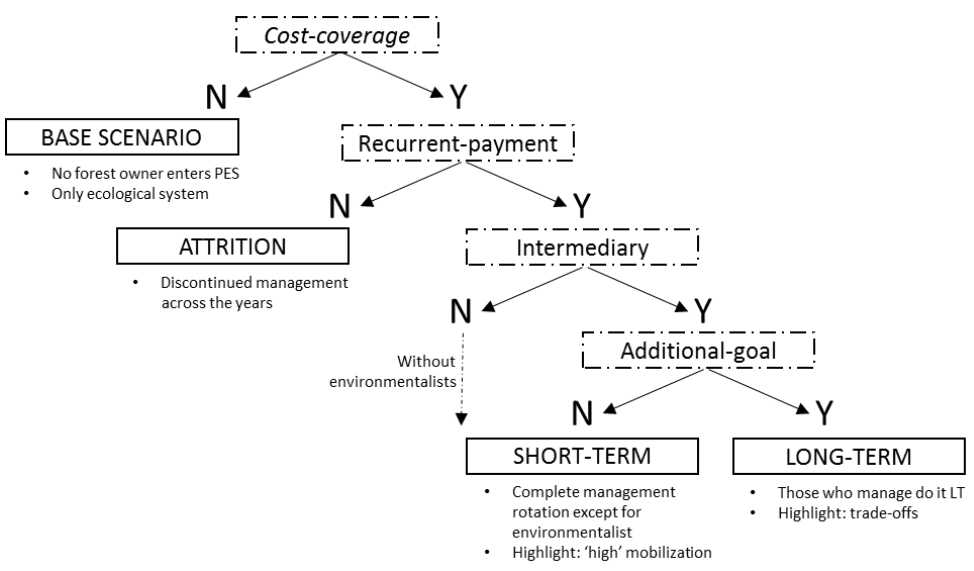

8. Additional: possible extensions

The first extension could include the introduction of private service users - who benefit from the provision of ecosystem services and would finance service providers. Currently, the model assumes it is a government-financed PES (Sven Wunder, 2015). An additional extension involving the type of management would be to reduce the forest mass. This could be implemented by modelling areas with certain risk, and reducing the size of the patches to represent less ha. Finally, another extension of the model could include the perception of forest fire risk in the current spatially explicit model. This could let forest owners estimate future consequences of their decisions. 


\section{References}

Briassoulis, H., \& McDonald, P. A. (2005). Policy Integration for Complex Environmental Problems The Example of Mediterranean Desertification. Taylor and Francis. Retrieved from http://wwwfr.redi-

bw.de/links/?rl_site=unifr\&rl_action=services\&sid=google\&auinit=H\&aulast=Briassoulis\&title=Po licy integration for complex environmental problems\%3A the example of Mediterranean desertification\&genre $=$ book\&isbn $=1351910523 \&$ date $=2017$

Cáceres, M. De, Martínez-Vilalta, J., Coll, L., Llorens, P., Casals, P., Poyatos, R., ... Brotons, L. (2015). Coupling a water balance model with forest inventory data to predict drought stress: The role of forest structural changes vs. climate changes. Agricultural and Forest Meteorology, 213, 77-90. https://doi.org/10.1016/j.agrformet.2015.06.012

Capodaglio, A. G., \& Callegari, A. (2018). Can payment for ecosystem services schemes be an alternative solution to achieve sustainable environmental development? A critical comparison of implementation between Europe and China. Resources, 7(3). https://doi.org/10.3390/resources 7030040

Deuffic, P., Sotirov, M., \& Arts, B. (2018). "Your policy, my rationale". How individual and structural drivers influence European forest owners' decisions. Land Use Policy, 79, 1024-1038. https://doi.org/10.1016/j.landusepol.2016.09.021

Fletas, M., Bayona, M., \& Cervera, T. (2012). Estructura de la propietat forestal de Catalunya. Anàlisi de dades cadastrals., 16. Retrieved from file:///C:/Users/Hp.DESKTOP-

C7KM867/Desktop/Literature/cadastre.pdf

FTiP. (2003). Pla de gestió de la conca del riu Rilb a la Baronia de Rialb (La Noguera).

Gracia, C., Sabaté, S., \& Sánchez, A. (2003). An integrated model of forest growth (Vol. Model docu).

ICEA. (2019). Reflexions sobre les politiques forestals del bosc privat a Catalunya.

Jack, B. K., Kousky, C., \& Sims, K. R. E. (2008). Designing payments for ecosystem services: Lessons from previous experience with incentive-based mechanisms. Proceedings of the National Academy of Sciences of the United States of America, 105(28), 9465-9470. https://doi.org/10.1073/pnas.0705503104

Nadal-Sala, D., Sabaté, S., Gracia, C., \& CPF. (2014). C4.2 Estudio sobre el riesgo de incendio y la disponibilidad de agua con GOTILWA+. LIFE+ DEMORGEST. ACCIÓN C4 - Seguimiento y evaluación del impacto sobre el problema ambiental. https://doi.org/10.14483/2248762x.8082

Piqué, M., Vericat, P., \& Beltrán, M. (2017). Orgest: Regional guidelines and silvicultural models for sustainable forest management. Forest Systems, 26(2), 1-6. https://doi.org/10.5424/fs/201726210627

Salzman, J., Bennett, G., Carroll, N., Goldstein, A., \& Jenkins, M. (2018). The global status and trends of Payments for Ecosystem Services. Nature Sustainability, 1(3), 136-144. https://doi.org/10.1038/s41893-018-0033-0

Sotirov, M., Sallnäs, O., \& Eriksson, L. O. (2017). Forest owner behavioral models, policy changes, and forest management. An agent-based framework for studying the provision of forest ecosystem goods and services at the landscape level. Forest Policy and Economics, 103, 79-89. https://doi.org/10.1016/J.FORPOL.2017.10.015

Wells, G., Ryan, C., Fisher, J., \& Corbera, E. (2020, June 1). In defence of simplified PES designs. Nature Sustainability. Nature Research. https://doi.org/10.1038/s41893-020-0544-3

Wunder, S., Brouwer, R., Engel, S., Ezzine-de-Blas, D., Muradian, R., Pascual, U., \& Pinto, R. (2020). Reply to: In defence of simplified PES designs. Nature Sustainability, 3(6), 428-429. https://doi.org/10.1038/s41893-020-0545-2

Wunder, S., Brouwer, R., Engel, S., Ezzine-De-Blas, D., Muradian, R., Pascual, U., \& Pinto, R. (2018). From principles to practice in paying for nature's services. Nature Sustainability, 1(3), 145-150. https://doi.org/10.1038/s41893-018-0036-x 